\title{
Smoothing State Tax Revenues over the Business Cycle: Gauging Fiscal Needs and Opportunities
}

\author{
Yolanda K. Kodrzycki
}

\begin{abstract}
:
The high degree of fiscal stress experienced by state governments in the 2001 and the 2007-2009 recessions has prompted renewed discussions of alternative approaches to stabilizing state finances over the business cycle. Prompted by evidence of increased state tax revenue cyclicality in the aggregate, this study explores state-specific patterns so as to inform policymakers in individual states. It finds that while elasticity levels continued to differ across states, most states experienced greater cyclical sensitivity in the 2000s than in the 1980s and 1990s. In addition, during the 2000s personal income tax receipts varied more over the business cycle than sales tax receipts in most states that imposed both forms of taxation. This trend represented a departure from the patterns of the prior two decades, when sales tax receipts were more cyclically sensitive than individual income tax receipts in the majority of states. Cross-section regressions reveal that the main source of variation in income tax elasticities across states during the 2000s was the cyclical sensitivity of their residents' incomes as reflected on their federal income tax returns. By contrast, state-specific features such as the tax treatment of capital gains or the progressivity of tax rates did not account for significant differences in revenue elasticities across states. In addition, state departures from the federal definitions of adjusted gross income and taxable income, on the whole, did not contribute to increased revenue volatility over the business cycle. The findings are used to evaluate the efficacy of alternative measures that could be used to help stabilize state revenues, including reforms of state tax and stabilization trust structures.
\end{abstract}

Keywords: state tax policy; revenue cyclicality; tax volatility; individual income tax JEL Classifications: $\mathrm{H} 2, \mathrm{H} 7$

Yolanda K. Kodrzycki is a vice president and economist in the research department at the Federal Reserve Bank of Boston, where she serves as the director of the New England Public Policy Center. Her e-mail address is yolanda.kodrzycki@bos.frb.org.

The author is grateful to Angela Cools for excellent research assistance, and to Leslie McGranahan, David Merriman, Bob Triest, and Bo Zhao for their insightful comments on an earlier draft. Participants in the Federal Reserve System Conference on Regional Analysis and the New England Public Policy Center brownbag seminar provided useful perspectives at an earlier stage of this research project.

This paper presents preliminary analysis and results intended to stimulate discussion and critical comment. The views expressed herein are those of the authors and do not indicate concurrence by the Federal Reserve Bank of Boston, or by the principals of the Board of Governors, or the Federal Reserve System.

This paper, which may be revised, is available on the web site of the Federal Reserve Bank of Boston at http://www.bostonfed.org/economic/wp/index.htm.

This version: October 30, 2014 


\section{Introduction}

Recessions precipitate heightened fiscal stress for state governments. Because state tax revenues are based heavily on incomes and spending, these receipts fall directly with downturns in the economy. Additional funding sources, such as state-accumulated rainy day funds or federal grants, rarely provide an adequate buffer to offset the combined decrease in tax revenues and the greater demand for social services associated with recessions. In order to comply with balanced-budget requirements, state governments usually must reduce discretionary spending in order to close their budget gaps. As a result, the provision of some categories of public services varies procyclically.

The last two national recessions were marked by an unusually high degree of fiscal stress for state governments. While the 2001 recession was brief and fairly mild, it resulted in very large budget shortfalls and protracted disagreements about the most appropriate state policy responses (Sheffrin 2004; Gonzalez and Levinson 2003). States again confronted abnormally sharp declines in tax receipts during the Great Recession of 2007-2009, with one study finding that 70 percent of state forecasts overestimated revenues by more than 5 percent during that period (Pew-Rockefeller 2011). Despite tapping into their own budget stabilization funds and the added federal grants provided by the American Recovery and Reinvestment Act, states continued to cut their payrolls for four years after the Great Recession officially ended.

The performance of state tax revenues during the 2000s has prompted renewed discussions of alternative approaches to stabilizing state finances over the business cycle (Jonas 2012; Mattoon and McGranahan 2012; and McGranahan and Mattoon 2012). Some analysts have urged state governments to accumulate larger rainy day funds during economic upturns or to relax their balanced budget constraints during economic downturns. Others have suggested that the federal government could be more proactive in assisting states that experience cyclical budget shortfalls or, alternatively, could provide incentives for states to build up their own rainy day funds - see McNichol and Boadi (2011), Galle and Stark (2012), Gamage (2010), Hines (2010), and Hou and Moynihan (2007). A related discussion revolves around how states could enact structural reforms that would decrease the cyclical sensitivity of their revenue streams. Some analysts have urged states to reduce their reliance on taxes that produce highly cyclical revenues. Others have focused on reforms of specific taxes, such as enacting a flatter income tax structure or increasing (decreasing) the taxation of relatively stable (highly volatile) elements of the tax base; for example, see Clemens (2012), Seegert (2012), and Sobel and Wagner (2003). 
A key question that these studies have not addressed is the degree to which individual states experienced elevated revenue cyclicality during the two most recent business cycles. Earlier research had found that states varied considerably in their degree of revenue cyclicality as a result of differences in tax mix, tax structures, and the willingness to adjust tax policy over the course of the business cycle (Holcombe and Sobel 1997; Dye and McGuire 1999). This paper updates the cross-state evidence on tax revenue cyclicality. In doing so, it provides state policymakers with the information they need to assess the extent and causes of revenue cyclicality, and to understand the efficacy of alternative approaches to mitigating the sensitivity of tax revenues to economic conditions.

The paper is organized as follows. The first section reexamines the findings on the sources of aggregate U.S. state tax revenue cyclicality in the 2000s. It confirms that the cyclical variability of personal income tax revenues increased markedly during this period. This increase occurred because taxable capital gains became more cyclical and accounted for a higher share of overall adjusted gross income (AGI) on tax returns than in previous decades. The cyclicality of capital gains tends to have a disproportionate effect on state income tax revenues compared to other sources of taxable income because capital gains are more concentrated in the top tax brackets.

The next section examines patterns in state-specific tax revenue cyclicality. While elasticity levels differ across states, most experienced greater cyclical sensitivity in the 2000s than in the 1980s and 1990s. During the 2000s, personal income tax receipts varied more over the business cycle than sales tax receipts in most of the states that imposed both forms of taxation. This variability represented a departure from the patterns of the prior two decades, when sales tax receipts were more cyclically sensitive than individual income tax receipts in the majority of states.

The following section studies the degree to which states could use tax reforms to change the cyclicality of their income tax revenues. Using cross-section regressions, I show that the main source of variation in income tax elasticities across states during the 2000s was the cyclical variability of their residents' incomes, as reflected in the federal definition of AGI. In other words, those states where federal AGI was more sensitive to economic conditions had more cyclically sensitive state income tax receipts, all other factors being equal. By contrast, state-specific features such as the tax treatment of capital gains or the progressivity of tax rates did not account for significant differences in revenue elasticities across states. Using data from 24 of the 40 states with a personal income tax (including states such as California, Connecticut, Massachusetts, and New Jersey and New York that rely heavily on income tax revenues), shows that state departures from the federal definitions of AGI and taxable 
income, taken as a whole, did not contribute to increased revenue volatility over the business cycle. The final section presents policy conclusions.

\section{Changes in Aggregate State Tax Revenue Cyclicality}

Movements in asset values and decisions on the timing of capital gains realizations have had major impacts on state finances in recent decades. Sjoquist, Stephenson, and Wallace (2011) estimate that income taxes on capital gains ranged from a low of about 6 percent to a high of about 17 percent of overall state income tax revenues during the 1990s and 2000s. The largest spikes in capital gains realizations occurred between 1995 and 2000, and between 2003 and 2007.

Several studies have shown that large swings in capital gains have contributed to the increasing cyclical variability of state tax revenues during this time period. Analyzing the 2001 recession, Maag and Merriman (2003) documented the unusually large declines in capital gains, along with policymakers' resistance to raising tax rates to offset the induced losses in revenue, as compared with the experiences during the 1990-1991 recession. More recently, the State Budget Crisis Task Force (2012) and the PewRockefeller (2011) report sounded similar themes with regard to the Great Recession of 2007-2009. McGranahan and Mattoon (2012) demonstrated that state tax revenues became far more sensitive to changing economic conditions in the 2000s as compared with the 1980 s to 1990 s, and that the rising responsiveness in state personal income tax revenues due to the higher variability of investment income was the key source of this uptick.

This section follows the approach used by McGranahan and Mattoon and confirms their key results on tax revenue elasticities. However, this paper yields a somewhat different conclusion regarding how the income tax base contributed to causing increased cyclical variation in total state income tax revenues during the 2000s. One of McGranahan and Mattoon's findings is that both total adjusted gross income (AGI) and the wage and salary component of AGI became more cyclical in the 2000s. However, it turns out that this result is sensitive to how economic conditions are measured. Using real per capita personal income rather than the Philadelphia Federal Reserve's coincident economic index as the summary economic statistic, the cyclical sensitivity of aggregate AGI and wages and salaries changed little if at all nationwide in the 2000s. This result has salience for state revenue departments because they tend to focus on personal income (rather than the coincident index) in their analytical and forecasting activities. 
Measuring Tax Revenue Cyclicality

Following the McGranahan and Mattoon specification, $b$, the short-run elasticity of state tax revenues $(R)$ with respect to state economic conditions $(Y)$, can be estimated by the following equation:

$$
\Delta \ln R_{i, t}=\alpha+b \Delta \ln Y_{i, t}+\varepsilon_{i t}
$$

where $\Delta \ln R_{i, t}$ is the year-over-year log difference in inflation-adjusted per capita revenues and $\Delta \ln Y_{\mathrm{i}, \mathrm{t}}$ is the year-over-year log difference in economic conditions in state $i$. This relationship is estimated separately for total tax revenues and five components: personal income, general sales, selective sales, corporate income, and all other. The dependent variable reflects both the automatic responses of tax revenues to economic conditions and any legislated changes made in response to the economy. In estimating this equation, observations with extreme changes in tax receipts are eliminated. ${ }^{1}$ The error term $\varepsilon_{\mathrm{it}}$ captures changes in revenue collections attributable to all other factors. ${ }^{2}$

\footnotetext{
${ }^{1}$ For total tax revenues and each major category for which elasticities are estimated (general sales, selective sales, personal income, corporate, and other), observations with year-over-year changes above 200 percent or below 50 percent were eliminated. Total tax revenue observations were also eliminated when general sales, selective sales, or income taxes displayed changes above 200 percent or under -50 percent. Finally, income tax and total tax data for Connecticut in 1991:Q3-Q4 and 1992:Q1-Q4 were excluded due to the introduction of a broad-based personal income tax. Across the full national sample, these exclusions had the largest impact on the corporate income tax series. Out of a potential 6,600 observations (50 states times 132 quarters), 381 observations of corporate income tax revenues were dropped because the year-over-year change was greater than 200 percent or less than -50 percent. The disparate impact on the corporate income tax series is not surprising, given the high degree of variability in corporate income and the fact that audits and court decisions involving large corporations can have a large impact on quarterly tax revenues. Many fewer observations were dropped because of extreme fluctuations in the other major components of tax revenues. Only 45 observations were dropped for personal income tax revenues, 10 for general sales tax revenues, 3 for selective sales tax revenues, and 31 for the "all other" category. By state, Alaska, Nevada, and New Mexico had the most observations dropped as a result of extreme revenue fluctuations. In the case of Alaska, the deleted observations were due mostly to fluctuations in corporate, severance, and other tax revenues. For Nevada and New Mexico, many of the omissions corresponded to quarters where the revenue data from the Census Bureau did not correspond to the data from state departments of revenue. As a robustness check, revenue elasticities also were estimated without omitting the outlier observations. In general, the data omissions affected the precision of some of the elasticity estimates (particularly for the corporate income tax and for states with a relatively large number of dropped observations), but not the major findings.

${ }^{2}$ These include both discretionary changes in tax policy that are unrelated to the state of the economy, as well as changes in tax revenue induced by other determinants. For example, tax revenues could change if taxpayers respond to anticipated changes in state tax law by shifting the timing of income or consumption. In addition, purchasing patterns can change for reasons that are not patterns. Also reflected in the error term would be tax collections associated with purchasing patterns that are not closely correlated with personal income. For example, durables purchases might reflect changes in the cost or availability of credit. Some studies address overall revenue volatility, which takes into account both revenue cyclicality and all other factors that cause revenues to change from period to period. Studies focusing on revenue volatility include Cornia and Nelson (2010), Crain (2003), Dye and McGuire (1991), Kwak (2013), and Yan (2013).
} 
This paper uses inflation-adjusted per capita personal income as the measure of a state's economic conditions. As compared with state GDP, which was used by Dye and McGuire (1999), personal income is available on a quarterly basis, and therefore is a more accurate indicator of the magnitude and duration of state recessions. Furthermore, personal income is typically used as an input to produce state revenue forecasts, and therefore may have greater salience for policymakers than the Philadelphia Federal Reserve's state coincident economic indexes, which are available quarterly and were the primary measure of business cycles used by McGranahan and Mattoon (2012). ${ }^{3}$

The parameter $B$ captures short-run revenue cyclicality, which is the average responsiveness of tax revenues to changes in personal income. If the absolute value of $B$ is greater than (less than) $1, \operatorname{tax}$ revenues are elastic (inelastic), meaning that these can be expected to increase by a larger (smaller) percentage than personal income. If $B$ is greater than (less than) 0 , tax revenues are procyclical (countercyclical), meaning that they tend to move in the same direction as (different direction from) personal income.

McGranahan and Mattoon determined that the elasticity of revenues with respect to economic conditions changed around 2000. We confirm the timing of the break point using Quandt likelihood ratio tests, and estimate the magnitude of the change in elasticity using the following panel regression:

$\Delta \ln R_{i, t}=\alpha_{11}+\alpha_{21}\left(2000 \_\& \_a f t e r\right)+b_{11} \Delta \ln Y_{i, t}+b_{21}\left(2000 \_\& \_a f t e r * \Delta \ln Y_{i, t}\right)+\varepsilon_{i t}$

where 2000_\&_after refers to a time dummy that equals 1 starting in $2000{ }^{4}$ The national average elasticity is significantly higher (lower) in the 2000 s if the estimate of $B_{21}$ is significantly higher (lower) than zero.

The source of revenue data is the U.S. Census Bureau's annual survey of state finances, with two key adjustments. First, an estimate of the revenues collected by states that flow directly to local governments are excluded from total state tax receipts. Arkansas, Michigan, Minnesota, Montana, New Hampshire and Vermont adopted statewide property taxes in the 1990s or early 2000s in order to equalize education funding across localities. Prior to the enactment of the new taxes, these states had minimal property tax revenues. It is assumed that state property tax revenues continued at

\footnotetext{
${ }^{3}$ McGranahan and Mattoon report that their results are robust to using nonfarm payroll employment to measure state-specific economic cycles.

${ }^{4}$ Quandt Likelihood Ratio tests with 15 percent trimming are performed, and break points allowed only in the first quarter of each year. Although slightly different timing for break points are achieved compared to those in McGranahan and Mattoon, the use of the 2000 break point is retained, as this is supported by high QLR for all years in the late 1990s and 2000s. (For total tax revenue, the QLR is 26.1 in 2000, 31.0 in 2006, and above 20 for all years after 1997. For the personal income tax, the QLR is 26.8 in 2000, 27.4 in 2001, and above 20 for most years in the 1990s and 2000s. Sales tax revenue displays a change during the Great Recession, with the QLR of 9.4 in 2000 and 23.3 in 2007.)
} 
approximately the same levels after the education reforms were enacted, and the remaining property tax collections are treated as local revenues. ${ }^{5}$

Second, states that levy only selective income taxes are excluded from the income tax regressions (while these types of taxes are included in total tax revenues). New Hampshire and Tennessee tax only dividends and interest income. Connecticut taxed only selective income categories prior to the establishment of a broad-based personal income tax in $1991 .^{6}$

The upper half of Table 1 presents the estimates of the elasticity of total tax revenues, its three largest components (personal income, general sales, and selective sales taxes), and two smaller categories (corporate income and all other). The main interest is in the estimated elasticity for 1980$1999\left(B_{11}\right)$ and differential elasticity for 2000-2012 $\left(B_{21}\right)$. The sum of these two parameters provides an estimate of the elasticity of state tax revenues in the 2000s.

The results confirm that the greater cyclical volatility of tax receipts in the 2000 s can be traced to the fluctuations in personal income tax receipts. The elasticity of total tax revenue with respect to personal income was 0.83 in the 1980 s to $1990 \mathrm{~s}$, and then increased to 1.76 in the 2000 s. This change is statistically significantly different from zero at the 1 percent confidence level. Of the three major revenue components, only the personal income tax showed a large and statistically significant increase, from 0.50 in 1980-1999 to 2.23 in 2000-2011. The estimated increase in the elasticity of general sales tax revenues (0.38) was insignificantly different from zero, while the estimated change in the elasticity of selective sales taxes was tiny. ${ }^{7}$ Corporate income tax revenues were more cyclically sensitive than the other categories in the 1980s and 1990s, and their sensitivity increased further in the 2000s. However, corporate taxes have a negligible influence on overall tax cyclicality because nationally these account for only 6 percent to 7 percent of total revenues. The bottom half of Table 1 shows the results

\footnotetext{
${ }^{5}$ Specifically, it was assumed that post-reform state property tax collections were equivalent to the average collections made beginning in 1994 to the year prior to reform (1994 was the first year in which the Census Bureau itemized property tax data). For the two states that enacted reforms prior to 1994 (Michigan and Montana), unpublished data provided by state revenue officials were used to calculate average pre-reform revenues. Separate averages were calculated on a quarterly, per-capita basis, and adjusted for inflation.

${ }^{6}$ On the other hand, I follow the Census Bureau practice by including in corporate income receipts some taxes whose base was much broader than the corporate income. Examples include the business enterprise tax in New Hampshire and the gross receipts tax in Delaware.

${ }^{7}$ Using a dummy variable starting in 2007 rather than 2000 in the sales tax regression yields an estimated elasticity increase of 0.521 that is significant at the 10 percent level. Further quarters of data are needed to obtain more conclusive evidence of a change in the cyclical sensitivity of sales tax revenues.
} 
of using the coincident economic index to measure the state of the economy. Not surprisingly, the estimates are very similar to those of McGranahan and Mattoon (2012). ${ }^{8}$

The (Un)Changing Cyclical Sensitivity of the Personal Income Tax Base

To estimate the changes in the sensitivity of the personal income tax base to economic conditions within a state, the following equation is used:

$\Delta \ln I n c_{i, t}=\alpha_{12}+\alpha_{22}\left(2000 \_\& \_a f t e r\right)+B_{12} \Delta \ln Y_{i, t}+b_{22}\left(2000 \_\& \_a f t e r * \Delta \ln Y_{i, t}\right)+\varepsilon_{i t}$

where Inc denotes real per capita federal AGI or one of its components. Most states use federal AGI as the starting point for their calculation of taxable personal income. The equation is estimated using annual data because taxpayers compute AGI in the course of filing their annual returns. ${ }^{9}$

Relative to personal income, I find that overall AGI was no more volatile during the 2000s than it had been during the 1980s and 1990s. Although there is substantial overlap between AGI and personal income-which would tend to make their cyclical patterns very similar-, one notable difference is that AGI includes realized capital gains (to the extent they are taxed by the federal government). By contrast, the U.S. Bureau of Economic Analysis measure of personal income refers to income from current economic activity and therefore does not encompass any changes in asset values. ${ }^{10}$

The top panel of Table 2 shows the results from using real per capita personal income to measure $\mathrm{Y}$. The estimated elasticity of overall AGI with respect to personal income $\left(\beta_{12}\right)$ is 0.97 in the 1980-99 period, and the estimated difference in this elasticity in the 2000-11 period $\left(\beta_{22}\right)$ is both small, 0.15 , and insignificantly different from zero. The estimated elasticity of wages and salaries is 0.80 during 1980-99, and is unchanged in the later years. These findings of stable elasticities contrast with the inference of increasing elasticities using the coincident index shown in the bottom panel. The reason for this discrepancy is that the coincident index became less volatile in the 2000 s relative to its prior history, while personal income did not. ${ }^{11}$

\footnotetext{
${ }^{8}$ For sensitivity, we also ran similar regressions excluding the ten states with the greatest reliance on severance taxes: Alaska, Kentucky, Louisiana, Montana, North Dakota, New Mexico, Oklahoma, Texas, West Virginia, and Wyoming. Throughout the paper we refer to these as the "mining states." The results were qualitatively similar.

${ }^{9}$ Because 2012 AGI data are not available, these regressions cover only 1980-2011.

${ }^{10} \mathrm{See}$ http://www.bea.gov/regional/pdf/spi2012.pdf (pages 16-17) for the components of BEA personal income. Since the Tax Reform Act of 1986, 100 percent of capital gains income has been included in AGI. Prior to the Act, only 40 percent of capital gains were included in AGI). See Nelson and Cronin, "Adjusted Gross Income," Tax Policy Center Tax Topics, Urban Institute and Brookings Institution.

Retrieved from http://www.taxpolicycenter.org/taxtopics/encyclopedia/Adjusted-Gross-Income.cfm.

${ }^{11}$ The standard deviation of the log difference of real personal income was about 0.02 in both the 1980s-1990s and the 2000s. The standard deviation of the log difference in the coincident index fell from 0.03 in the earlier period to 0.02 in the later period. The coincident index is a weighted average of four indicators: payroll employ-
} 
In contrast with the patterns for total federal AGI and wages and salaries, investment income became much more cyclical in the 2000s. During the 1980s and 1990s, a 1 percentage point increase in personal income was associated with a 1.13 percent increase in overall investment income and a 2.21 percent increase in capital gains. During the 2000s, these responses rose dramatically to 4.68 percent and 4.03 percent, respectively. These findings are qualitatively similar to those measuring responses to changes in the coincident index.

The share of investment income that contributed to the ratio of investment income to federal AGI was approximately the same in the 2000s as it had been in the 1980 s and 1990s. However, in the earlier decades the share of capital gains was 4 percent but increased to 6 percent in the 2000s, while the share attributable to interest and dividends fell. Therefore the rise in the cyclicality of capital gains realizations had an outsized effect in increasing the cyclicality of overall AGI.

Other sources of personal income went from being very procylical in the 1980s to 1990s to being virtually acyclical in the 2000s. The non-wage non-investment portion of AGI has three distinct components: retirement income (Social Security, pensions, and withdrawals from personal retirement accounts), transfer payments, and entrepreneurial income (from unincorporated businesses, Scorporation profits passed through directly to shareholders, and property ownership). Separate elasticities can only be estimated for the 2000s, owing to a lack of state data for the earlier decades (Table 3). ${ }^{12}$ As expected, retirement income excluding social security was not very cyclical. ${ }^{13}$ Transfer payments were highly countercyclical but accounted for only a small share of the income claimed on personal tax returns. All Other income (consisting largely of entrepreneurial income) was surprisingly acyclical in the 2000s. It appears that businesses' increased adoption of the S-corporation and partnership forms of organization mitigated the cyclical swings in entrepreneurial income throughout this period.

Summarizing the results of this section, using federal AGI as a proxy for state income tax bases and using personal income to measure the business cycle, the overall income state tax base did not become more cyclically sensitive in the 2000s. This lack of greater cyclical responsiveness reflected two countervailing forces: the much greater cyclical sensitivity of capital gains combined with a higher share

ment, the unemployment rate, the manufacturing workweek, and inflation-adjusted wage and salary disbursements. Wage and salary disbursements are the largest component of personal income, which also includes interest, dividends, rent, and transfer payments. The exact reason for the decline in volatility in the coincident index during the 2000s is not clear, but one contributing factor might be that work stoppages became less prevalent in the manufacturing sector, which resulted in greater stability in the manufacturing workweek.

${ }^{12}$ Breakdowns by component of other income are available starting in 1997. 
of capital gains in overall income, on the one hand, and the reduced cyclical sensitivity of non-wage, non-investment income on the other.

The increased volatility of aggregate state income tax receipts can be explained by the fact that capital gains flow disproportionately to the highest-income taxpayers, who account for a large fraction of income tax revenues in many states. Throughout almost the entire sample period, the concentration of capital gains among upper-income households was far greater than the concentration of wages and salaries, and even somewhat higher than other types of investment income (Congressional Budget Office 2011). ${ }^{14}$ Chernick, Reimers, and Tennant (2014) estimated that over 80 percent of capital gains in 2007 were realized by the top 5 percent of taxpayers, and indicated that most states with an income tax subject capital gains to ordinary income tax rates. Thus, the volatility of capital gains has had a disproportionate effect on state income tax revenues. In addition, research by Parker and VissingJorgensen (2010) suggests that the high cyclicality of labor income among very high earners may have been an additional contributing factor. ${ }^{15}$

\section{Measuring Tax Revenue Cyclicality across States}

States differ in the cyclicality of their tax revenues because both their economies and tax policies differ. However, differences in business cycles are largely due to factors such as industry mix and competitiveness, factors that are outside the control of state policymakers in the short- to mediumrun. ${ }^{16}$ This section extends the analytical framework to examine the extent to which individual state tax revenues became more procyclical in the 2000s. A particular focus is on the contribution of state personal income taxes to increases in cyclical variability, since this is the component driving the nationwide pattern.

\section{Historical Evidence}

Past studies have documented the historical connections between a state's tax structure and its revenue cyclicality. Prior to the 1960s, states tended to rely heavily on selective excise taxes and other

\footnotetext{
${ }^{14}$ The Congressional Budget Office study covers the period from 1979 to 2007.

${ }^{15}$ Parker and Vissing-Jorgensen demonstrate that since the early 1980s, the non-capital-gains income of the top 1 percent of taxpayers has been 2.4 times as cyclical as that of all taxpayers. The relatively high cyclicality of earned income among the top 1 percent was the largest contributing factor to this discrepancy. In addition, the authors cite another study indicating that the share of income of the top 1 percent rose from 8.0 percent in 1981 to 17.7 percent in 2008. See Hardy and Ziliak (2014) for analysis of income variability and income shares of families at different points of the income distribution.

${ }^{16}$ A study by The Pew Charitable Trusts (2014) examines how industrial composition affects tax revenue cyclicality across states.
} 
narrowly based revenue sources to fund their expenditures. For the most part, these revenues did not fluctuate much relative to personal income, either because the taxes were imposed on items whose sales were not income-elastic or because the taxes varied only with the quantity purchased, but not the total amount spent. The results in Table 1 indicate that revenues from selective sales taxes continue to vary relatively little over the business cycle.

During the 1960s and early 1970s, a number of states introduced broad-based personal income taxes and general sales taxes. Over the long run, revenues from these sources grow with increasing incomes and consumer spending, thereby helping states to satisfy the growing demand for public services in response to population increases or a greater willingness to pay for such services. On the other hand, these new forms of taxation produced more cyclical revenue inflows compared to the traditional sources of state funding (Holcombe and Sobel 1997). Thus the adoption of broad-based taxes also meant that the level of public services provided by states would tend to vary more over the business cycle in the absence of explicit fiscal stabilization policies (such as adjusting tax rates to offset revenue surpluses or shortfalls, or making use of rainy day funds).

Income and retail sales taxes continued to grow in importance in the 1980s and 1990s. By the 2000s, general sales taxes and personal income taxes combined to account for two-thirds of state tax revenues, up from two-fifths in the 1960s (Figure 1), and together accounted for just under one-half of total (tax and non-tax) own-source revenues. Revenues from individual income taxes increased as a share of overall taxes because taxable personal incomes grew faster than other major state tax bases (Holcombe and Sobel 1997). ${ }^{17}$ In addition, because states tended not to adjust their income tax brackets for inflation or real growth, effective tax rates increased as rising incomes pushed individuals into higher tax brackets. ${ }^{18}$ However, states also reduced statutory income tax rates and expanded deductions and exemptions periodically. These adjustments had the effect of limiting the growth of income tax revenues. Over time, retail sales grew somewhat more slowly than incomes, ${ }^{19}$ but states tended to

\footnotetext{
${ }^{17}$ These authors used adjusted gross income for federal income tax purposes as a proxy for state taxable income. Many states derive their definitions of taxable income from federal AGI.

${ }^{18}$ Holcombe and Sobel found that 37 of the 41 states with personal income taxes had faster growth in income tax revenues than in the underlying income tax base over the period from 1972 to 1993.

${ }^{19}$ Examining the period between the early 1970s through the early 1990s, Holcombe and Sobel (1997) found that the long-run elasticity of retail sales with respect to personal income averaged 0.55 , while the long-run elasticity of AGI with respect to personal income averaged 0.89 . These figures refer to the estimates from an error correction model; the estimates from a simpler log-difference specification were similar. See Dye (2004) for further evidence that the choice between an error-correction and a log-difference specification has little effect on estimated elasticities.
} 
raise statutory sales tax rates, thereby causing sales tax revenues to increase noticeably as a share of overall tax revenues (Seegert 2012).

Studies using data from the 1970s to 1990s found that the design of income and sales taxes influenced the cyclical properties of state revenues. For example, Holcombe and Sobel (1997) concluded that " $[t]$ he evidence is mixed on whether the personal income tax is more or less stable than retail sales taxes that exempt food" (p. 142). Bruce, Fox, and Tuttle (2006) indicated that "[C]ontrary to conventional wisdom, neither the personal income tax nor the sales tax emerges as the universally more volatile tax" (p. 338), and Dye and McGuire (1991) emphasized that states that adopted narrow sales taxes and progressive income taxes would likely see far greater revenue variability than those adopting broad sales taxes and flat income tax rates.

\section{Updated Elasticity Estimates}

With recent studies documenting the heightened cyclicality of overall state personal income tax revenues in the 2000s, it is worthwhile to reexamine the cyclicality of tax revenues across states. The relevant questions include the degree to which individual states experienced more cyclical tax revenues in the 2000s, as well as the relationship between a state's overall increase in cyclicality and factors such as its dependence on personal income tax revenues, the share of capital gains in its personal income tax base, and its rate structure.

Table 4 provides the key information on state income taxes and tax bases in the 2000s. California and New York stand out as being very vulnerable to cyclical fluctuations. Both states were highly dependent on personal income tax revenues (44 percent and 58 percent, respectively), had high marginal tax rates for well-to-do taxpayers (between 9.3 percent and 10.3 percent for California and between 6.5 percent and 8.82 percent for New York), and had high shares of capital gains in federal AGI (7 percent and 8 percent, respectively). The other states with a high capital gains share in AGI and either a high reliance on the personal income tax or high top brackets were Colorado, Connecticut, Idaho, Massachusetts, and Vermont. Minnesota, North Carolina, and Oregon had a high reliance on the personal income tax and high top rates, but low ratios of capital gains to AGI. At the other extreme, nine states (Alaska, Florida, Nevada, New Hampshire, South Dakota, Tennessee, Texas, Washington, and Wyoming) lacked a broadbased personal income tax. Therefore, their share of income from capital gains was irrelevant in contributing to revenue volatility.

To test whether or not the estimated elasticity of tax revenues for a given state differs from the national average, I estimate the following equation using panel data from 1980-1999 and 2000-2012:

$$
\Delta \ln R_{i, t}=\alpha_{13}+\alpha_{23}(\text { state })+b_{13} \Delta \ln Y_{i, t}+b_{23}\left(\text { state } * \Delta \ln Y_{i, t}\right)+\varepsilon_{i t}
$$


where state refers to a state dummy variable. Appendix Tables 1, 2, and 3 present the detailed results. In these three tables, Columns 1 and 2 show the estimated elasticities of total tax revenues, personal income tax revenues, and general sales tax revenues, respectively, for each individual state (i.e., the fitted values of $B_{13}$ ) in each sub-period. The asterisks in these columns indicate whether the estimated state-specific elasticities are statistically significantly different from the 50-state average (i.e., whether $B_{23}$ is significantly different from zero). For convenience, these Appendix Tables repeat the 50 -state estimates derived earlier, and also show comparable results for the 10 mining and 40 non-mining states. The term "mining states" refers to states with relatively heavy reliance on severance taxes. (These states are listed in footnote 8 ).

To test whether or not the change in the elasticity for a given state is different from the average change among all states, the following equation is estimated using the entire sample period from 1980 to 2012:

$$
\begin{aligned}
& \Delta \ln R_{i, t}=\alpha_{15}+\alpha_{25}(\text { state })+\alpha_{35}\left(2000 \_\& \_a f t e r\right)+\alpha_{45}\left(\text { state } * 2000 \_\& \_a f t e r\right)+b_{15} \Delta \ln Y_{i, t} \\
& +B_{25}\left(\text { state }^{*} \Delta \ln Y_{i, t}\right)+B_{35}\left(2000 \_\& \text { _after } * \Delta \ln Y_{i, t}\right)+b_{45}\left(\text { state } * 2000 \_\& \text { after } * \Delta \ln Y_{i, t}\right)+\varepsilon_{i t}
\end{aligned}
$$

The last columns in Appendix Tables 1, 2, and 3 indicate the change in revenue elasticity during the 2000-2012 period as compared with the 1980-1999 period (i.e., the fitted values of $B_{35}$ ), and whether this change was statistically significantly different from the 50 -state average change (i.e., whether $B_{45}$ is significantly different from zero).

Several clear patterns emerge from these state-specific estimates.

Widespread increases in cyclical sensitivity of tax revenues. The national pattern of increasing state tax revenue elasticity in the 2000 s was mirrored in many states. As shown in Table 5, many more states had increases in total tax cyclical sensitivity (39) than had decreases (11)). Increases in income tax elasticities were pervasive and contributed to the overall increase in revenue cyclicality. Of the 41 states with personal income taxes in both periods, 34 experienced increased cyclical sensitivity in the 2000s.

Geographic variation in revenue cyclicality reflective of income and tax mix. Not surprisingly, California and New York were among the states with very cyclically sensitive income tax revenues in the 2000s (see Table 6). Most of the other states with high estimated elasticities (more than two standard deviations above the national average) were located in the northeastern, southeastern, or far western regions of the country. Included in this category were the three New England states with high capital gains income and either a high reliance on the personal income tax or a high top income tax rate: Connecticut, Massachusetts, and Vermont. At the other extreme, the three non-mining states without 
a broad-based income tax-Florida, New Hampshire, and Nevada-had fairly stable tax revenues in the 2000s, compared to movements in their state economies.

Higher elasticities for income taxes than for sales taxes. During the 2000s, income tax revenues showed more cyclical volatility than sales tax revenues in the overwhelming majority of states. Of the 38 states with both a broad-based income tax and a broad-based sales tax, only five (Hawaii, Kentucky, Louisiana, Nebraska, and North Dakota) had higher estimated short-run elasticities for sales taxes than for income taxes (shown in Table 7). Interestingly, all of these states have progressive income tax rates, a feature that is usually thought to increase the cyclical sensitivity of revenues because very high-income taxpayers tend to have more cyclically sensitive incomes than middle-income taxpayers. ${ }^{20}$

Changes in the relative volatility of income and sales taxes over time. These patterns are very different from those in the 1980s and 1990s, when general sales tax revenues were more cyclically sensitive than individual income taxes in 27 states of the 38 states with both forms of taxation. For example, Massachusetts, which had very elastic income tax revenues in the 2000s (Table 6), experienced less cyclical sensitivity in income tax revenues than sales tax revenues during the 1980-1999 period (Table 7) The other states with similar patterns were Alabama, Arizona, Georgia, Maryland, Michigan, North Carolina, Ohio, and South Carolina. On the other hand, seven other states with highly cyclically sensitive income tax revenues in the 2000s (California, Connecticut, New Mexico, New York, and Vermont, Virginia, and Wisconsin) were among the minority of states where income taxes fluctuated more with the business cycle than did sales taxes in the 1980s and 1990s.

\section{What Can State Policymakers Do to Reduce Income Tax Fluctuations?}

This section investigates the degree to which state policymakers could have foreseen the rise in income tax cyclicality during the 2000s and taken preemptive steps to reduce it. Furthermore, to what degree could a restructuring of state income taxes reduce the likelihood of volatile income tax revenues in the future?

These questions are explored in two ways. The first approach involves running a regression analysis in order to determine the systematic determinants of the differences in income tax elasticities across states for the 2000-2012 period (shown in Table 8). The first hypothesis is that cross-state patterns are

\footnotetext{
${ }^{20}$ In Louisiana, the finding appears to be due to the surge in replacement purchases in the wake of Hurricane Katrina. See http://www.nytimes.com/2006/06/26/us/26louisiana.html?_r=3\&oref=login\&oref=slogin\&.
} 
related to historical patterns, specifically the estimated state income tax elasticities in the prior decade. The underlying idea is that the basic structure of state tax rates, deductions, and exemptions does not change greatly from one decade to the next. For example, only a couple of states switched between flat and graduated income tax rates during the sample period. This is because tax structures tend to reflect resident preferences that vary more across states than across time periods within a given state.

The regression analysis indicates that the estimated cross-state revenue elasticity patterns in the 2000 s bear essentially no relationship to the estimated cross-state revenue elasticity patterns in the 1990s, as shown in Table 8. ${ }^{21}$ The hypothesis that the coefficient on lagged elasticity is different from zero cannot be rejected, and the adjusted $R^{2}$ is only .02 (column 1). This result is not really surprising, given the previous section's discussion of states whose income taxes were highly cyclically sensitive in the 2000 s but not in the 1980 s-1990 period. However, a similar regression relating state revenue elasticities in the 1990s to their values in the 1980s indicates a much higher degree of correlation (column 8). In other words, the historical patterns were of greater usefulness in predicting revenue variability in the 1990 s than they proved to be in the 2000 s.

Row 2 includes a second independent variable, the estimated elasticity of AGI on federal income tax returns for the 2000s. (These elasticities were obtained by running a regression of the log- difference of real per capita federal AGI on the log-difference of real per capita personal income and a constant term by state annually for the 2000-2011 period.) The differences in AGI elasticity across states largely reflect their residents' income sources, and how these various income sources are treated under the federal tax code. State-specific income tax policies affect the composition of state tax bases, but to a lesser degree. ${ }^{22} \quad$ The estimated elasticity of AGI on federal income tax returns is highly statistically significant, and its estimated coefficient of 1.06 indicates that a 1 percentage point increase in the cyclical sensitivity of incomes had a nearly equivalent effect on the cyclical sensitivity of its income tax revenues in the 2000s. The coefficient on lagged elasticity $(0.245)$ is roughly the same as it was in the first specification, while the constant term (representing the average increase in revenue elasticity after accounting for lagged revenue elasticity and the federal AGI elasticity) drops to $1.16 .{ }^{23}$ The adjusted $R^{2}$ rises to 0.211 .

\footnotetext{
${ }^{21}$ The estimated state income tax revenue elasticity for the preceding decade is used because the true elasticity is not observable. Essentially, the regression tests whether the historical observations would have been useful in anticipating the cyclical sensitivity of income tax revenues in the 2000s.

${ }^{22}$ For evidence on the role of state personal income taxes see Bruce, Fox, and Zhou (2010).

${ }^{23}$ Because the federal AGI elasticity is estimated via a regression, its coefficient will be downwardly biased. Using the Stata eivreg command and assuming that 30 percent of the variance in this the estimated federal AGI elasticity across states is due to noise, its estimated coefficient rises to 1.518. The coefficient on lagged state income tax
} 
Finally, the role of several specific features of state income tax codes that varied across states in the $2000 \mathrm{~s}$ is examined. The hypothesis being tested is that states with higher (lower) tax rates on cyclically sensitive income sources should have more (less) cyclical variation in tax revenues, all else equal. Row 3 includes an indicator for the preferential treatment of capital gains income. This feature of state tax codes is measured by a dummy variable that equals one if capital gains are taxed at a lower rate than ordinary income. While a negative coefficient was expected, the estimated coefficient turns out to be small, positive, and insignificantly different from zero. In table 8, row 4 includes the income threshold for the highest personal income tax bracket. This variable is also expected to enter with a negative sign because the lower the threshold, the greater is the fraction of the state's taxpayers that face the top marginal tax rate. This coefficient is also insignificantly different from zero. Additional indicators of tax progressivity were tried, including the highest marginal tax rate, the number of tax brackets, and a dummy equaling one if the state had graduated income tax rates (not shown). None entered significantly. As a robustness check, the regressions in columns (2) to (4) were repeated without using the lagged elasticity term. The results, shown in columns (5) to (7), are virtually unchanged.

These findings on state-specific tax features are consistent with those reported in Chernick, Reimers, and Tennant (2014). Their analysis showed that that the interaction between the fall in realized capital gains and the income tax treatment of the highest income taxpayers resulted in large drops in income tax revenues during the Great Recession in a few states, but that differences in tax progressivity accounted for little of the overall variation in revenue volatility across states.

One factor that may have contributed to the findings both in Chernick, Reimers, and Tennant (2014) and in this study is the fact that states with graduated income tax rates reacted somewhat differently to recession-induced revenue drops than states with a single income tax rate. Several states with progressive rate structures (including Connecticut, Hawaii, Maryland, New Jersey, and Oregon) either added new high-rate and high-threshold tax brackets or significantly raised tax rates more broadly to cope with revenue declines associated with the Great Recession. By contrast, most states that had flat income tax rates during the 2000-2012 period (including Colorado, Indiana, Massachusetts, Michigan, and Pennsylvania) either kept income tax rates unchanged or changed them procyclically (see the footnotes to Table 4 for details on the individual states).

revenue elasticity is virtually unchanged $(0.262)$, and the estimated constant term falls to 0.635 . Thus, while there is some uncertainty about the exact relationship between the dependent variable and federal AGI elasticity, the substantive conclusions drawn from the results shown in the second row of Table 8 appear to be robust. The additional inferences derived from the cross-section regressions (shown in the remaining rows of Table 8 ) also continue to hold. 
To summarize, in the 2000s differences in the income tax volatility across states were systematically related to differences in the income volatility on their residents' federal income tax returns. The more cyclically variable taxpayer incomes were, the more cyclically variable were the state revenues derived from the personal income tax. By contrast, the preferential treatment of capital gains and the degree of tax rate progressivity did not have a statistically significant bearing on revenue volatility. It appears that one of the reasons for the lack of correlation between these state-specific policies and the cyclicality of personal income tax revenues may have been that states with graduated rates were more likely to raise their tax rates to make up for recession-induced revenue shortfalls than states with flat rates.

While the regressions did not find systematic ways in which state tax codes affect the cyclical variability of income tax receipts, it is still possible that certain states have provisions that affect the volatility of their tax collections. Thus, the second approach involves analyzing state and federal tax base data for individual states. Prior research has assumed that the AGI on federal income tax returns is a close proxy for taxable income on state income tax returns because most states have taxpayers provide information from their federal returns as the starting point for calculating their state income tax liability. While many states adopt the federal definition of $A G I$, a few start with federal taxable income (AGI less personal exemptions and standard or itemized deductions). In either case, however, at least some tax deductions and exemptions are state-specific. Moreover, the individual states vary greatly in the size of deductions and personal and dependent exemptions. They also differ with respect to whether or not federal income taxes are deductible from the state's calculation of taxable income, and in the tax treatment of Social Security and pension income.

The key reason why prior studies have not attempted this sort of analysis is that the data are difficult to obtain. There is no central repository for such information, and the states themselves often do not maintain the needed data in a format that is accessible to researchers. By examining state department of revenue websites and contacting state officials, I was able to obtain information for 23 states covering six or more years during the 2000s.

To answer the question of whether state tax bases were more cyclically volatile than federal tax bases, the elasticities of $A G I$ and taxable income with respect to state personal income are compared on state and federal income tax returns filed by residents of a given state. Separate regressions for each state were conducted using the availability of state data to determine the estimation period. For the most part, the analysis suggests that state departures from the federal definitions of AGI and taxable income did not lead to greater volatility over the business cycle, at least in the limited sample of states and years where data are available. States with cyclically sensitive state-level AGI and taxable income 
tended to be the same ones that had cyclically sensitive federal-level AGI and taxable income (see Figure 2). And while, on balance, the cyclical sensitivity of state AGI tended to be a little higher than the cyclical sensitivity of federal AGI, the cyclical sensitivities of state taxable income and federal taxable income were quite similar. The detailed regression results for each of these 23 states are provided in Appendix Table 4.

There were some exceptions to the sensitivity of state and federal taxable income to economic conditions, although these differences were not dramatic. For example, in Maryland, the estimated elasticity of state taxable income with respect to personal income was 4.37 , noticeably higher than the estimated elasticity of federal taxable income, 3.60. But even if Maryland had conformed to the federal definition, its tax base would have been more cyclically sensitive than those of any of the other 22 states in the sample. In addition to Maryland, nine other states' federal income tax bases showed twice as much cyclical variation as their personal income: Arizona, California, Hawaii, Massachusetts, New York, Ohio, Pennsylvania, Rhode Island, and South Carolina.

\section{Conclusions}

State tax revenues were more volatile than their economies in the period from 2000 to 2012 . For every 1 percentage point increase (decrease) in real per capita personal income, real per capita tax revenues increased (decreased) by 1.8 percentage points.

Personal income tax revenues account for over one-third of total state tax revenues, and tend to be the largest source of tax revenues in the 41 states that tax personal income. Over the last decade, these income tax revenues became much more cyclically sensitive. During the 2000s, a 1 percentage point increase in real per capita income resulted in a 2.2 percentage point increase in income tax receipts in these states. Personal income tax revenues were especially cyclically volatile in Alabama, Arizona, California, Connecticut, Georgia, Maryland, Massachusetts, Michigan, North Carolina, New Mexico, New York, Ohio, Oregon, South Carolina, Virginia, Vermont, and Wisconsin.

The research finds that differences in the variability of personal income tax receipts across states were closely tied to the variability of their residents' federal adjusted gross income/AGI over the business cycle. State policymakers have little control over the federal AGI of taxpayers in their state, as this is determined by residents' sources of income and on laws governing how different income sources are treated for federal tax purposes. Investment income was highly variable in the early 2000 s, owing to sharp swings in capital markets and taxpayers' decisions of when to recognize capital gains or losses. 
Although states often specify adjustments to federal tax bases in determining state-level AGI and state-level taxable income, for the most part these adjustments appear not to affect the cyclical variability of state tax bases to any appreciable degree. For the 23 states (out of 41 with an income tax) with available data, state taxable income and federal taxable income showed similar cyclicality in the 2000-2011 period. In nine states, the swings in both federal and state taxable income were at least twice as great as the swings in personal income: Arizona, California, Hawaii, Maryland, Massachusetts, New York, Ohio, Oregon, and Rhode Island.

It is not possible to predict whether state tax revenues will continue to be more volatile than their economies. Nonetheless, the findings in this paper offer guidance to state policymakers who are considering alternative measures to smooth their revenues over the business cycle. The most radical tax policy reform would be to eliminate broad-based income and sales taxes altogether. The research has shown that for every 1percent increase (decrease) in real per capita personal income, real per capita selective sales tax revenues increase (decrease) by about 0.5 percent. However, a complete reliance on these relatively inelastic forms of taxation would conflict with other tax policy goals such as equity, efficiency, and adequacy. New Hampshire is the only non-mining state without a broad-based income or sales tax. Instead, its revenues come mostly from taxing corporate income, selective categories of individual incomes, and selective categories of retail sales. This paper has shown that for each 1 percent increase (decrease) in real per capita personal income, New Hampshire tax collections increased (decreased) by about 0.8 percent since 2000. The most obvious drawback to adopting a NewHampshire-style tax structure is that it likely would not raise enough revenues to pay for the public services that most states choose to provide. New Hampshire is a high-income state with a low poverty rate, and these circumstances reduce the need for government services. In addition, the state has chosen to limit the size or scope of public services it provides (Weiner 2011).

Another option would be to for states to decrease their dependence upon the personal income tax and increase their reliance on sales and other tax sources. This paper estimates that for each 1 percent increase (decrease) in real per capita personal income during the 2000s, real per capita sales tax collections increased (decreased) by about 1.4 percent. There are three major concerns with a strategy that shifts the burden to sources other than the personal income tax. First, sales taxes tend to be regressive, a fact that may limit their appeal to voters in some states. Second, the comparative cyclical stability of the sales tax may have been a temporary phenomenon. In the 1980s and 1990s, sales tax revenues were more sensitive to economic conditions in 26 of the 38 states that imposed both a personal income tax and sale taxes. Furthermore, this study finds some evidence that the cyclicality of 
sales tax revenues rose in the late 2000s. ${ }^{24}$ Whether this development was a temporary phenomenon attributable to changes in spending patterns during the Great Recession, or indicative of a longer lasting structural shift in consumer buying behavior, remains to be seen. Finally, without continual increases in sales tax rates or major expansions of the sales tax base to include more categories of consumer spending, the growth in sales tax revenues may not be adequate to keep pace with the rising demand for public services. This is because tax-exempt purchases (such as for higher education, health care, and other services) are absorbing increasing shares of household budgets. The final option for state-level tax reform would be to reduce the progressivity of state personal income taxes, either by changing the rate structure or by altering state-level preferences for capital gains. The evidence presented in this paper indicates that the existing differences across state income tax laws contributed very little during the 2000s to making the income tax revenues in some states more cyclically stable than in other states. The implication is that, in order to substantially reduce the elasticity of its personal income tax revenues with respect to personal income, a state would likely have to revise its tax code very substantially. Alternatively, it would have to be willing to raise tax rates when income tax receipts plummeted and reduce these rates when receipts boomed. While the latter action is common, the political reality is that rate hikes are particularly unpalatable when taxpayer incomes are falling. If anything, the evidence from the 2000s suggests that states with flat rate schedules were less likely to increase income taxes to make up for revenue shortfalls during the Great Recession than were states with graduated rates. This may have been because, for a given revenue target, attempting to raise income tax rates in the context of a flat-rate tax would likely have engendered greater popular resistance than adjusting rates for higher income taxpayers.

All in all, the research presented in this paper suggests that the most viable way for states to avoid large spending swings over the business cycle while adhering to balance budget requirements would be to allocate some portion of unexpectedly strong revenue receipts to budget stabilization funds. Massachusetts recently started to put aside capital gains revenues in excess of a threshold level into a rainy day fund). ${ }^{25}$ Other states might want to consider adopting some variant of the Massachusetts model. In addition, when revisions to federal laws cause taxable incomes to increase temporarily (such as, for example, accelerating the recognition of income from capital gains), states may want to set aside their windfall revenues in a stabilization fund.

\footnotetext{
${ }^{24}$ See footnote 4.

${ }^{25}$ See Section 5 G of Chapter 29 in the Massachusetts General Laws. For a discussion of the factors that motivated the state to adopt a statutory capital gains threshold, see Huff (2008).
} 


\section{References}

Bruce, Donald, William F. Fox, and M. H. Tuttle. 2006. "Tax Base Elasticities: A Multi-State Analysis of Long-Run and Short-Run Dynamics." Southern Economic Journal 73(2): 315-341.

Bruce, Donald, William F. Fox, and Zhou Yang. 2010. "Base Mobility and State Personal Income Taxes."

National Tax Journal 63(4, Part 2): 945-966.

Chernick, Howard, Cordelia Reimers, and Jennifer Tennant. 2014. "Tax Structure and Revenue Instability: The Great Recession and the States." IZA Journal of Labor Policy 3:3.

Clemens, Jeffrey. 2012. "State Fiscal Adjustments During Times of Stress: Possible Causes of the Severity and Composition of Budget Cuts." Working Paper, November 2.

Congressional Budget Office. 2011. "Trends in the Distribution of Household Income between 1979 and 2007." October. Washington, DC. Available at http://www.cbo.gov/sites/default/files/cbofiles/attachments/10-25-Householdlncome.pdf.

Cornia, Gary C., and Ray D. Nelson. 2010. "State Tax Revenue Growth and Volatility." Federal Reserve Bank of St. Louis Regional Economic Development 6:1:23-58.

Crain, W. Mark. 2003. Volatile States: Institutions, Policy, and the Performance of American State Economies. Ann Arbor: The University of Michigan Press.

Dye, Richard F. 2004. "State Revenue Cyclicality." National Tax Journal 57(1): 133-145.

Dye, Richard F., and Therese J. McGuire. 1991. "Growth and Variability of State Individual Income and General Sales Taxes." National Tax Journal 4(1): 55-66.

Dye, Richard F., and Therese J. McGuire. 1999. "State Fiscal Systems and Business Cycles: Implications for State Welfare Spending When the Next Recession Occurs." Discussion Paper 99-04. Washington, DC: The Urban Institute.

Galle, Brian, and Kirk J. Stark. 2012. "Beyond Bailouts: Federal Supports for State Rainy Day Funds." Indiana Law Journal 87(2): 599-644.

Gamage, David. 2010. "Preventing State Budget Crises: Managing the Fiscal Volatility Problem." California Law Review 98(3): 749-812. Giertz, J. Fred and Seth H. Giertz. 2004. "The 2002 Downturn in State Revenues: A Comparative Review and Analysis." National Tax Journal 57(1): 111-132.

Gonzalez, Christian, and Arik Levinson. 2003. "State Rainy Day Funds and the State Budget Crisis of 2002-?" State Tax Notes 29(6): 441-451.

Hardy, Bradley, and James P. Ziliak. 2014. "Decomposing Trends in Income Volatility: The 'Wild Ride' at the Top and Bottom." Economic Inquiry 52(1): 459-476. 
Hines, James R., Jr. 2010. "State Fiscal Policies and Transitory Income Fluctuations." Brookings Papers on Economic Activity 41(2): 313-342.

Holcombe, Randall G., and Russell S. Sobel. 1997. Growth and Variability in State Tax Revenue: An Anatomy of State Fiscal Crises. Westport, CT: Greenwood Press.

Hou, Yilin, and Donald P. Moynihan. 2007. "The Case for Countercyclical Fiscal Capacity." Journal of Public Administration Research and Theory 18(1): 139-159.

Huff, Cameron. 2008. "Capital Gains: Avoiding Harm to the State Budget." MassINC Fiscal Policy Brief 2 (December). Available at http://www.massinc.org/ /media/Files/Mass\%20Inc/Research/Full\%20Report\%20PDF\%20files/cap gai ns.ashx.

Jonas, Jiri. 2012. "Great Recession and Fiscal Squeeze at U.S. Subnational Government Level." IMF Working Paper 12/184. Washington, DC: International Monetary Fund. Available at https://www.imf.org/external/pubs/ft/wp/2012/wp12184.pdf.

Kwak, Sunjoo. 2013. "Tax Base Composition and Revenue Volatility: Evidence from the U.S. States." Public Budgeting \& Finance 33(2): 41-74.

Maag, Elaine, and David Merriman. 2003. "Tax Policy Responses to Revenue Shortfalls." Research report prepared for conference, State Fiscal Crises: Causes, Consequences, \& Solutions, April 3. Washington, DC: The Urban Institute. Available at http://www.urban.org/UploadedPDF/410798 tax policy responses.pdf.

Mattoon, Rick, and Leslie McGranahan. 2012. "State and Local Governments and the National Economy." In The Oxford Handbook of State and Local Government Finance, ed. Robert D. Ebel and John E. Petersen, 137-155. New York: Oxford University Press.

McGranahan, Leslie, and Richard Mattoon. 2012. "Revenue Cyclicality and Changes in Income and Policy." Public Budgeting \& Finance 32(4): 95-119.

McNichol, Elizabeth, and Kwame Boadi. 2011. "Why and How States Should Strengthen Their Rainy Day Funds: Recession Highlighted Importance of Funds and Need for Improvements." Washington, DC: Center on Budget and Policy Priorities. Available at http://www.cbpp.org/files/2-3-11sfp.pdf.

Nelson, Susan C., and Julie-Anne Cronin. "Adjusted Gross Income," Tax Policy Center Tax Topics, Urban Institute and Brookings Institution. Retrieved from http://www.taxpolicycenter.org/taxtopics/encyclopedia/Adjusted-Gross-Income.cfm.

Parker, Jonathan A., and Annette Vissing-Jorgensen. 2010. "The Increase in Income Cyclicality of HighIncome Households and Its Relation to the Rise in Top Income Shares. Brookings Papers on Economic Activity 41(2): 1-55. 
Pew Charitable Trusts. 2014. "Managing Uncertainty: How State Budgeting Can Smooth Revenue Volatility." Washington, DC: The Pew Charitable Trusts. Available at http://www.pewtrusts.org/ /media/Imported-and-

Legacy/uploadedfiles/pcs assets/2014/VolatilityManagingUncertaintypdf.pdf.

Pew Center on the States and the Nelson A. Rockefeller Institute of Government. 2011. "States' Revenue Estimating: Cracks in the Crystal Ball," Washington, DC: The Pew Charitable Trusts. Available at http://www.pewtrusts.org/ /media/Assets/2011/03/01/003 11 Rl-States-Revenue-EstimatesReport v1040711.pdf?la=en.

Seegert, Nathan. 2012? "Optimal Taxation with Volatility: A Theoretical and Empirical Decomposition." Unpublished Working Paper. Available at http://www-

personal.umich.edu/ seegert/papers/OptimalTaxationwithVolatility_Seegert.pdf.

Sheffrin, Steven M. 2004. "State Budget Deficit Dynamics and the California Debacle." Journal of Economic Perspectives 18(2): 205-226.

Sjoquist, David L., Andrew V. Stephenson, and Sally Wallace. 2011. "The Impact of Tax Revenue from Capital Gains Realizations on State Income Tax Revenue and Budget Conditions." Public Budgeting \& Finance 31(4): 31-50.

Sobel, Russell S., and Gary A. Wagner. 2003. "Cyclical Variability in State Government Revenue: Can Tax Reform Reduce It?" State Tax Notes 29(8): 569-576.

State Budget Crisis Task Force Report. 2012. New York: State Budget Crisis Task Force. Available at http://www.statebudgetcrisis.org/wpcms/wp-content/images/Report-of-the-State-Budget-Crisis-TaskForce-Full.pdf.

Weiner, Jennifer. 2011. "How Does New Hampshire Do It? An Analysis of Spending and Revenues in the Absence of a Broad-Based Income or Sales Tax?" New England Public Policy Center Research Report 111. Boston: Federal Reserve Bank of Boston. Available at http://www.bostonfed.org/economic/neppc/researchreports/2011/neppcrr1101.pdf.

Yan, Wenli. 2013. "Using Trend Data to Evaluate the Differential Response of State Borrowing to Revenue Volatility." Public Budgeting \& Finance 33(3): 75-92. 


\begin{tabular}{|c|c|c|c|c|c|c|}
\hline \multirow{2}{*}{\multicolumn{7}{|c|}{ Elasticity of State Tax Revenue Relative to the Personal Income }} \\
\hline & & & & & & \\
\hline & Total & Personal Income & General Sales & Selective Sales $^{1}$ & Corporate Income & All Other \\
\hline \multirow[t]{2}{*}{ Year-Over-Year Log-Difference in Personal income } & $0.829 * * *$ & $0.500^{*}$ & $1.022 * * *$ & $0.480^{* *}$ & $1.077^{* *}$ & $0.816^{* * *}$ \\
\hline & (0.129) & $(0.274)$ & $(0.216)$ & (0.184) & $(0.405)$ & $(0.287)$ \\
\hline \multirow[t]{2}{*}{ Log-Difference in Personal Income 2000 and After } & $0.934 * * *$ & $1.732^{* * *}$ & 0.378 & -0.021 & $0.925^{*}$ & $0.853^{*}$ \\
\hline & $(0.156)$ & $(0.368)$ & $(0.275)$ & $(0.220)$ & $(0.521)$ & $(0.452)$ \\
\hline \multirow[t]{2}{*}{ Dummy $=1$ if 2000 or Later } & $-0.018^{* * *}$ & $-0.054 * * *$ & $-0.016 * * *$ & 0.006 & 0.016 & 0.001 \\
\hline & $(0.004)$ & $(0.008)$ & $(0.006)$ & (0.008) & $(0.014)$ & $(0.010)$ \\
\hline \multirow[t]{2}{*}{ Constant } & 0.005 & $0.031^{* * *}$ & 0.001 & -0.000 & -0.005 & $-0.010^{*}$ \\
\hline & $(0.003)$ & $(0.006)$ & $(0.005)$ & $(0.006)$ & $(0.011)$ & $(0.005)$ \\
\hline \multirow[t]{3}{*}{ Observations } & 6,430 & 5,239 & 5,859 & 3,597 & 5,499 & 3,566 \\
\hline & \multicolumn{6}{|c|}{ Elasticity of State Tax Revenue Relative to the Coincident Indicator } \\
\hline & Total & Personal Income & General Sales & Selective Sales $^{1}$ & Corporate Income & All Other ${ }^{1}$ \\
\hline & & & & & & \\
\hline \multirow[t]{2}{*}{ Year-Over-Year Log-Difference in the Coincident Indicator } & $0.699 * * *$ & $0.563^{* * *}$ & $0.850 * * *$ & 0.010 & $1.409 * * *$ & 0.502 \\
\hline & $(0.062)$ & $(0.069)$ & $(0.102)$ & $(0.165)$ & $(0.115)$ & $(0.376)$ \\
\hline \multirow[t]{2}{*}{ Log-Difference in the Coincident Indicator 2000 and After } & $0.699 * * *$ & $1.494^{* * *}$ & 0.258 & 0.267 & $1.285^{* * *}$ & 0.442 \\
\hline & $(0.109)$ & $(0.138)$ & $(0.170)$ & $(0.191)$ & $(0.264)$ & $(0.454)$ \\
\hline \multirow[t]{2}{*}{ Dummy $=1$ if 2000 or Later } & -0.004 & $-0.036 * * *$ & -0.005 & -0.004 & $0.035^{* * *}$ & 0.012 \\
\hline & $(0.004)$ & $(0.006)$ & $(0.005)$ & $(0.010)$ & $(0.010)$ & $(0.016)$ \\
\hline \multirow[t]{2}{*}{ Constant } & 0.003 & $0.027^{* * *}$ & -0.000 & 0.014 & $-0.022 * * *$ & -0.005 \\
\hline & $(0.002)$ & $(0.003)$ & $(0.003)$ & $(0.009)$ & $(0.006)$ & $(0.015)$ \\
\hline Observations & 6,422 & 5,234 & 5,851 & 3,597 & 5,494 & 3,566 \\
\hline Memo: Revenues as Percent of Total Tax Revenues & Total & Personal Income & General Sales & Selective Sales $^{1}$ & Corporate Income & All Other ${ }^{1}$ \\
\hline \multicolumn{7}{|l|}{ 1980-99 } \\
\hline State Average (Unweighted) & 100.0 & 31.7 & 27.9 & $\mathrm{n} / \mathrm{a}$ & 6.8 & $\mathrm{n} / \mathrm{a}$ \\
\hline Nationwide State Total & 100.0 & 32.7 & 31.4 & $\mathrm{n} / \mathrm{a}$ & 7.5 & $n / a$ \\
\hline \multicolumn{7}{|l|}{$2000-2012$} \\
\hline State Average (Unweighted) & 100.0 & 31.5 & 31.3 & 17.3 & 5.6 & 14.3 \\
\hline Nationwide State Total & 100.0 & 32.3 & 35.1 & 15.5 & 5.9 & 11.3 \\
\hline
\end{tabular}




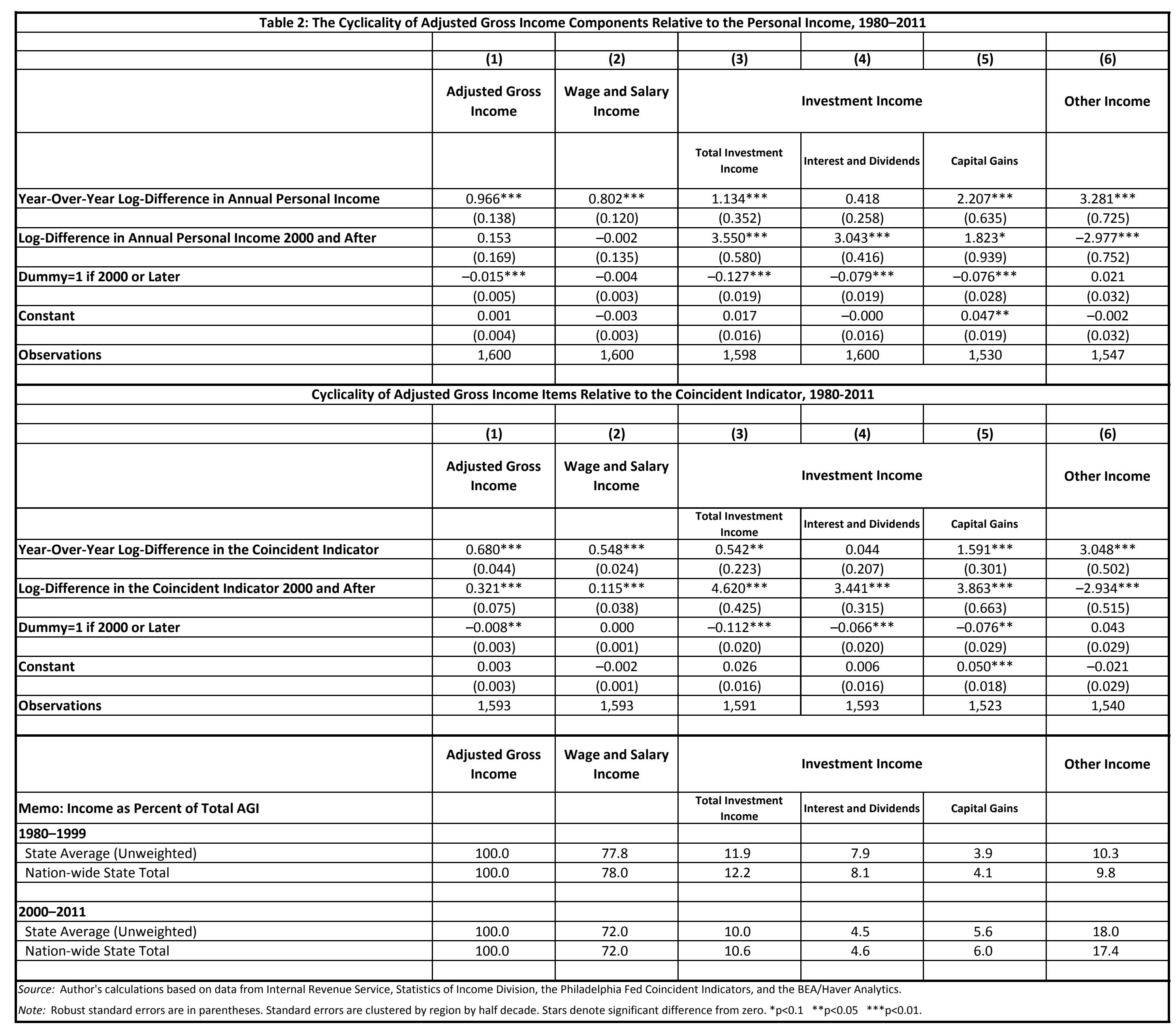




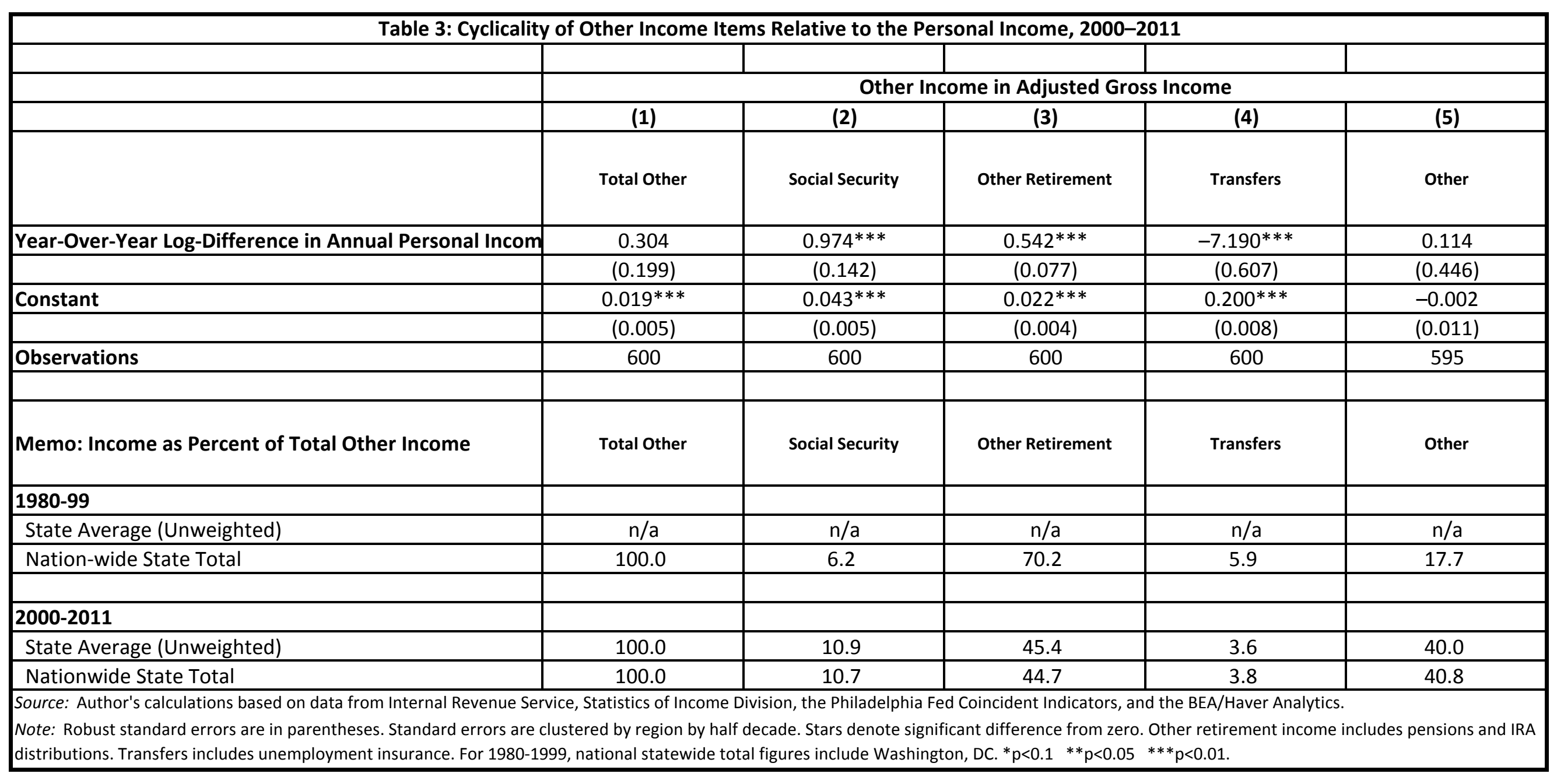




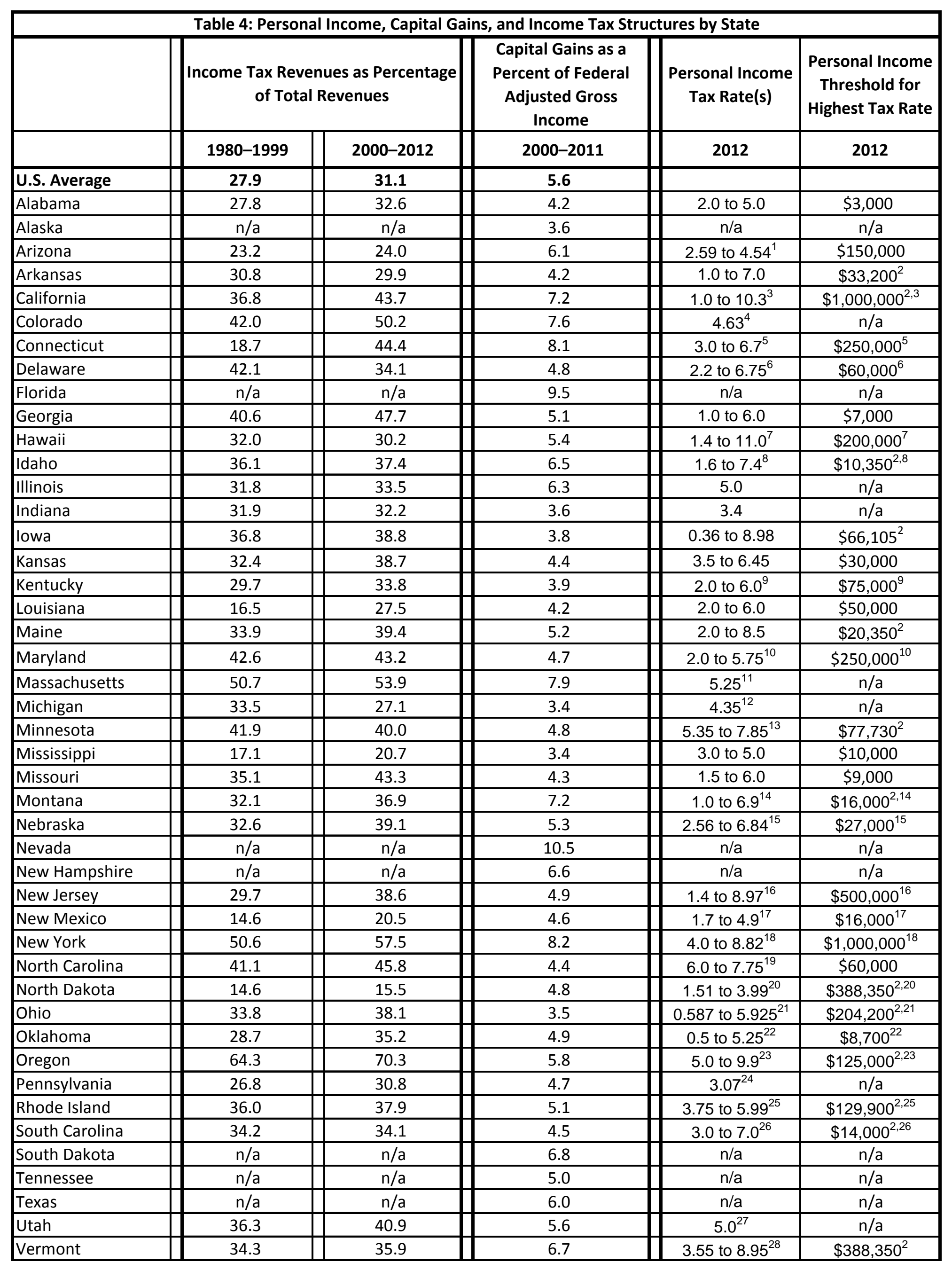




\begin{tabular}{|l||c|c|c|c|c|}
\hline Virginia & 46.7 & 53.9 & 5.0 & 2.0 to 5.75 & $\$ 17,000$ \\
\hline Washington & $\mathrm{n} / \mathrm{a}$ & $\mathrm{n} / \mathrm{a}$ & 6.8 & $\mathrm{n} / \mathrm{a}$ & $\mathrm{n} / \mathrm{a}$ \\
\hline West Virginia & 25.0 & 29.8 & 3.1 & 3.0 to 6.5 & $\$ 60,000$ \\
\hline Wisconsin & 41.2 & 42.3 & 4.6 & 4.6 to $7.75^{29}$ & $\$ 232,660^{2}$ \\
\hline Wyoming & $\mathrm{n} / \mathrm{a}$ & $\mathrm{n} / \mathrm{a}$ & 12.6 & $\mathrm{n} / \mathrm{a}$ & $\mathrm{n} / \mathrm{a}$ \\
\hline
\end{tabular}

Source : Author's calculations based on data from Internal Revenue Service, Statistics of Income Division; Huff, Cameron "Capital Gains: Avoiding Harm to the State Budget," MassINC Fiscal Policy Brief, December 2008; Tax policy center State Individual Income Tax Rates reports.

Note: Alaska, Florida, Nevada, New Hampshire, South Dakota, Tennessee, Texas, Washington, and Wyoming do not levy a broad-based income tax.

${ }^{1}$ Arizona's personal tax rates were 2.87 to 5.04 percent from 2000-2006.

${ }^{2}$ Indexed to inflation.

${ }^{3}$ California's personal tax rates ranged from 1.0 to 9.3 from 2009-2011. Additional taxation on incomes over \$1 million began in 2005.

${ }^{4}$ Colorado's personal tax rate decreased from 5.0 to 4.63 in 2001.

${ }^{5}$ Connecticut added a new bracket for personal incomes over $\$ 500,000$ in 2009, with a rate of 6.5 percent. (In 2012, this was altered to a rate of 6.9 percent on incomes over $\$ 250,000$.) Prior to this, the top marginal rate was 5.0 percent (4.5 until 2004), and the top bracket began at $\$ 10,000$.

${ }^{6}$ Delaware's top percentage rate changed was 6.95 from 2010-2011, 5.95 from 2001-2009, and 6.40 (with a top bracket beginning at $\$ 30,000$ ) in 2000.

${ }^{7}$ Hawaii added an additional tax bracket for incomes over $\$ 200,000$ in 2009. Prior to this, the highest tax rate was 8.25 percent for incomes over $\$ 40,000$ (8.75 from 2000-2001).

${ }^{8}$ Idaho's top tax rate was 7.8 percent from 2003-2011, 8.1 in 2001, and 8.2 in 2000. Prior to 2012, tax brackets were inflation-adjusted, and the top bracket was approximately $\$ 25,000$.

${ }^{9}$ Kentucky's top bracket increased from $\$ 8,000$ to $\$ 75,000$ in 2006.

${ }^{10}$ Beginning in 2009, Maryland's top rate was 5.5 percent on personal incomes over $\$ 500,000$. It also had a 6.5 rate on incomes over $\$ 1$ million from 2009-2010. The highest tax rate (on incomes over \$3000) was 4.75 from 2002-2008, and 4.85 from 2000-2001.

${ }^{11}$ Massachusetts taxes capital gains at 12 percent. Massachusetts' tax rate on all other income was 5.3 from 2004-2011, 5.6 from 2002-2003, 5.85 in 2001, and 5.95 in 2000.

${ }^{12}$ Michigan's personal tax rate was 3.9 percent from 2005-2008, 4.0 in 2004, 4.1 in 2003, 4.2 in 2002, 4.2 in 2001, and 4.4 in 2000.

${ }^{13}$ Minnesota's rates were 5.5 to 8.0 in 2000.

${ }^{14}$ Montana's rates were 2 to 11 percent from 2000-2004. In these years, the top personal tax bracket was approximately $\$ 75,000$.

${ }^{15}$ Nebraska's rates were 2.51 to 5.68 percent from 2000-2004. The top personal tax bracket increased from $\$ 26,500$ to $\$ 27,000$ in 2007 .

${ }^{16} \mathrm{New}$ Jersey introduced an 8.97 percent tax rate for incomes above $\$ 500,000$ in 2004 . Prior to this, the top personal income tax bracket was $\$ 75,000$ with a rate of 6.37 percent. From 2009-2010, the rate was increased to 10.75 percent for income above $\$ 1,000,000$.

${ }^{17} \mathrm{New}$ Mexico's top rate decreased from 8.2 (with a top bracket at $\$ 65,000$ ) to 7.7 percent (with a top bracket of $\$ 42,000$ ) in 2004 , to 6.8 percent (with a top bracket at $\$ 26,000$ ) in 2005 , to 5.7 (with a top bracket of $\$ 16,000$ ) in 2006, to 5.3 percent (with a top bracket of 16,000 ) in 2007, and to 4.9 percent (with a top bracket of $\$ 16,000$ ) in 2009.

${ }^{18} \mathrm{New}$ York's top rate was 6.5 percent (incomes over $\$ 20,000$ ) in 2000, 6.85 percent (incomes over $\$ 20,000$ ) in 2001 and $2003,6.85$ percent (incomes over $\$ 40,000$ ) in 2002, 7.75 percent (incomes over $\$ 500,000$ ) in 2004, 7.7 percent (incomes over $\$ 500,000$ ) from 2005-2006, 6.85 percent (incomes over $\$ 20,000$ ) from 2007-2009, and 8.97 percent (incomes over $\$ 500,000$ ) effective 2009-2011.

${ }^{19}$ North Carolina's top rate was 7.75 percent (incomes over $\$ 60,000$ ) in $2000,8.25$ percent over $\$ 120,000$ from 2002-2007, 8 percent over $\$ 120,000$ in 2008 , and then removed in 2009. It's top bracket of 7.75 percent was temporarily increased to $\$ 100,000$ in 2010.

${ }^{20}$ Until 2001, North Dakota's personal tax rate was 14 percent of federal liability. North Dakota's tax rates were 2.1 to 5.54 percent (with top rate at inflation-adjusted figure over $\$ 300,000$ ) from $2002-2008$, and 1.84 to 4.86 percent (with top rate at inflation-adjusted figure over $\$ 300,000$ ) from 2009-2011.

${ }^{21}$ Ohio's top personal tax rate declined from roughly 7 percent (for incomes over $\$ 200,000$ ) from 2000-2008 to approximately 6 percent (for incomes over $\$ 200,000)$ from 2009-2011.

${ }^{22}$ Oklahoma's top personal tax rate declined from roughly 7 percent (for incomes over $\$ 10,000$ ) from 2000-2006 to 6.25 percent (incomes over $\$ 10,000$ ) in 2007, and 5.5 percent from 2008-2011 (incomes over $\$ 10,000$ ).

${ }^{23}$ Oregon's top rate was 11 percent (incomes above $\$ 250,000$ ) from 2009-2011, and 9 percent (incomes over approximately $\$ 6,000-\$ 7,000$ ) from 2000-2008.

${ }^{24}$ Pennsylvania's personal tax rate increased from 2.8 to 3.07 percent in 2003.

${ }^{25}$ Rhode Island's personal tax rates changed from 25 percent of federal tax liability from 2000-2001, to progressive rates between 3.75 and 9.9 percent (over $\$ 373,650$ ) from 2002-2010, and 3.75 to 5.99 percent (over $\$ 125,000$ ) in 2011.

${ }^{26}$ The table reflects South Carolina's lowest positive tax rate. South Carolina's bottom rate decreased from 2.5 to 0 percent in 2009. Over the period $2000-2011$, the income threshold for the top rate ranged from $\$ 11,500$ to $\$ 12,000$.

${ }^{27}$ Utah's personal tax rates changed from progressive rates between 2.3 and 7 percent from 2000-2006 to a flat rate of 5 percent in 2007.

${ }^{28}$ Vermont's personal tax rates changed from 25 percent of federal income tax liability from 2000-2002 to progressive rates from 3.60 to 9.50 percent from 2003-2006 (max approximately $\$ 300,000$ and inflation adjusted each year), to 2.4 to 9.5 percent from 2007-2009 (reduced to 9.4 percent in 2009 , max rate effective at approximately $\$ 350 \mathrm{k})$, and 8.95 percent thereafter.

${ }^{29}$ Wisconsin's top tax rate increased from 6.75 to 7.75 percent in 2009. 


\begin{tabular}{|c|c|c|}
\hline \multicolumn{3}{|c|}{$\begin{array}{l}\text { Table 5: Changes in Total and Income Tax Elasticity by State, 2000-2012 } \\
\text { Change in Tax Elasticity, 2000-2012 vs. 1980-1999 }\end{array}$} \\
\hline & Total Tax & Income Tax \\
\hline Increased Elasticity in the 2000s & 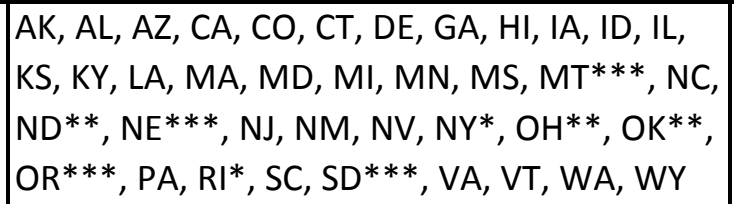 & $\begin{array}{l}A L, A R^{*}, A Z^{* * *}, C A, C O, C T, D E, G A, I A, I D, I L, \\
K S, K Y, L A, M A, M D, M I^{*}, M N, M O, M T, N C \\
N D^{* *}, N E, N J, N M, N Y, O H^{* *}, O R^{*}, P A, R I, \\
S C^{* * *}, V A, V T, W V^{* *}\end{array}$ \\
\hline Decreased Elasticity in the 2000s & $\begin{array}{l}\mathrm{AR}^{* * *}, \mathrm{FL}^{* * *}, \mathrm{IN}^{* *}, \mathrm{ME}^{* * *}, \mathrm{MO}, \mathrm{NH}^{*} \\
\mathrm{TN}^{* * *}, \mathrm{TX}^{* *}, \mathrm{UT}, \mathrm{WI} \mathrm{I}^{* * *}, \mathrm{WV}^{* * *}\end{array}$ & $\mathrm{HI}, \mathrm{IN}^{*}, \mathrm{ME}^{* * *}, \mathrm{MS}^{* *}, \mathrm{OK}^{* * *}, \mathrm{UT}^{* * *}, \mathrm{WI}^{*}$ \\
\hline
\end{tabular}




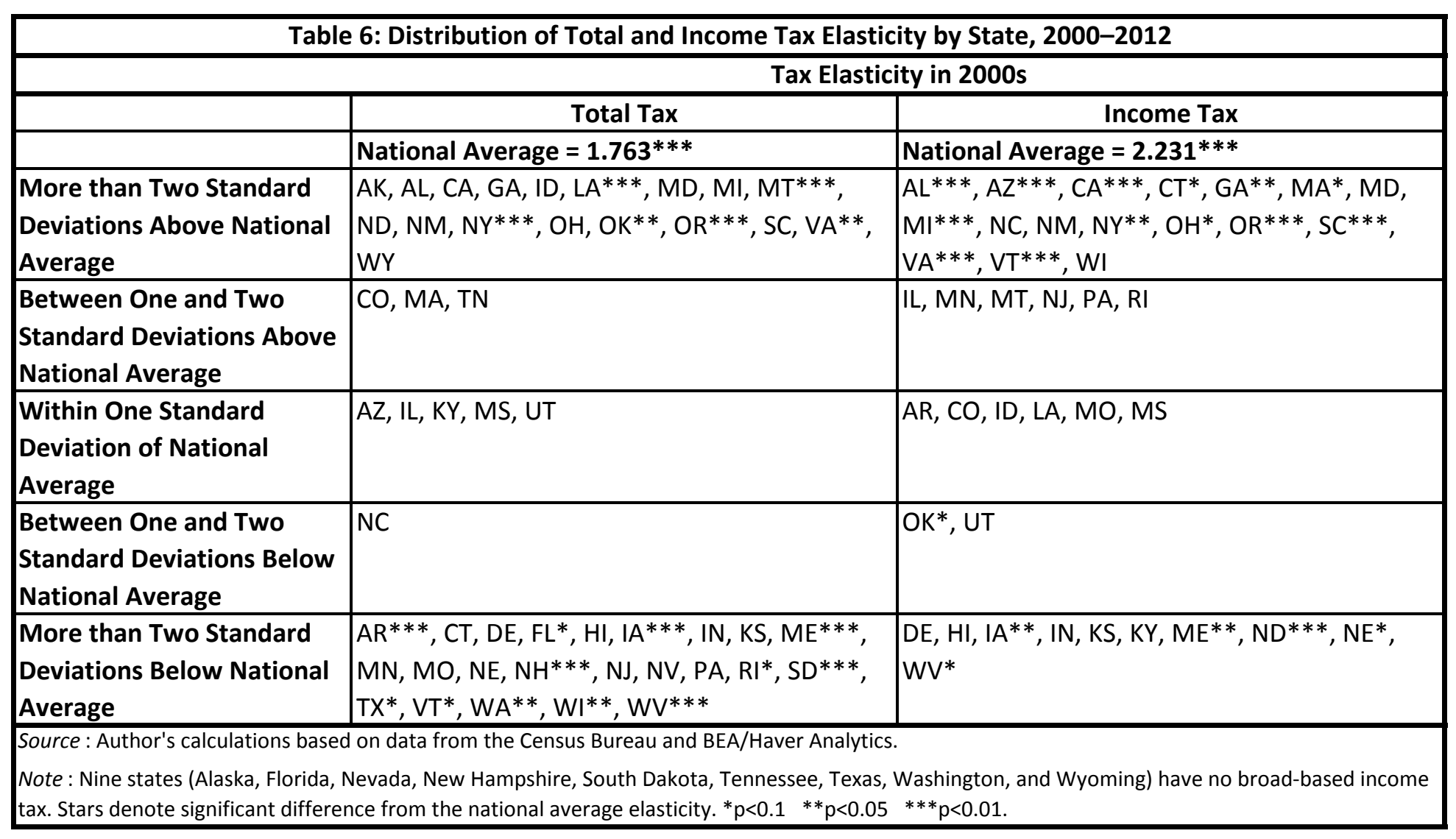




\begin{tabular}{|c|c|c|c|}
\hline & & 1980-1999 & $2000-2011$ \\
\hline \multirow{2}{*}{$\begin{array}{l}\text { Income Tax Revenues } \\
\text { More Cyclical Than } \\
\text { General Sales Tax } \\
\text { Revenues }\end{array}$} & Number of States: & 12 & 33 \\
\hline & States: & $\begin{array}{l}\mathrm{CA}, \mathrm{CT}, \mathrm{HI}, \mathrm{IA}, \mathrm{IN}, \mathrm{ME}, \mathrm{NM}, \\
\mathrm{NY}, \mathrm{UT}, \mathrm{VA}, \mathrm{VT}, \mathrm{WI}\end{array}$ & $\begin{array}{l}\text { AL, AR, AZ, CA, CO, CT, GA, } \\
\text { IA, ID, IL, IN, KS, MA, MD, } \\
\text { ME, MI, MN, MO, MS, NC, } \\
\text { NJ, NM, NY, OH, OK, PA, RI, } \\
\text { SC, UT, VA, VT, WI, WV }\end{array}$ \\
\hline \multirow{2}{*}{$\begin{array}{l}\text { General Sales Tax } \\
\text { Revenues More Cyclical } \\
\text { Than Income Tax Revenues }\end{array}$} & Number of States: & 26 & 5 \\
\hline & States: & $\begin{array}{l}\text { AL, AR, AZ, CO, GA, ID, IL, } \\
\text { KS, KY, LA, MA, MD, MI, } \\
\text { MN, MO, MS, NC, ND, NE, } \\
\text { NJ, OH, OK, PA, RI, SC, WV }\end{array}$ & $\mathrm{HI}, \mathrm{KY}, \mathrm{LA}^{1}, \mathrm{ND}, \mathrm{NE}$ \\
\hline \multicolumn{4}{|c|}{$\begin{array}{l}\text { Source: Author's calculations based on data from the Census Bureau and BEA/Haver Analytics. } \\
\text { Note: States are reported only if they have both a broad-based sales and broad-based income tax. Five states (Alaska, Delaware, Montana, } \\
\text { New Hampshire, and Oregon) have no broad-based sales tax, while nine states (Alaska, Florida, Nevada, New Hampshire, South Dakota, } \\
\text { Tennessee, Texas, Washington, and Wyoming) have no broad-based income tax. } \\
{ }^{1} \text { Total sales tax revenues (including selective sales taxes) less cyclical than income tax revenues 2000-2012. }\end{array}$} \\
\hline
\end{tabular}




\begin{tabular}{|c|c|c|c|c|c|c|c|c|}
\hline & \multicolumn{8}{|c|}{ Dependent Variable: Income Tax Elasticity } \\
\hline & \multicolumn{7}{|c|}{$2000-2012$} & \multirow{2}{*}{$\frac{1990-1999}{(8)}$} \\
\hline & (1) & (2) & (3) & (4) & (5) & (6) & (7) & \\
\hline \multirow[t]{2}{*}{ State Income Tax Revenue Elasticity 1990-1999 } & 0.207 & $0.245^{*}$ & 0.226 & $0.259 *$ & & & & \\
\hline & $(0.155)$ & $(0.139)$ & $(0.144)$ & $(0.140)$ & & & & \\
\hline \multirow[t]{2}{*}{ Federal AGI Elasticity 2000-2011 } & & $1.059 * * *$ & $1.108^{* * *}$ & $1.050 * * *$ & $1.009 * * *$ & $1.093 * * *$ & $1.000 * * *$ & \\
\hline & & $(0.332)$ & $(0.344)$ & $(0.332)$ & $(0.340)$ & $(0.351)$ & $(0.342)$ & \\
\hline \multirow[t]{2}{*}{ Capital Gains Preference } & & & 0.332 & & & 0.529 & & \\
\hline & & & $(0.553)$ & & & $(0.549)$ & & \\
\hline & & & & & & & & \\
\hline \multirow[t]{2}{*}{ Income Threshold for Top Marginal Tax Rate (Thousands) } & & & & 0.00247 & & & 0.00202 & \\
\hline & & & & $(0.00251)$ & & & $(0.00257)$ & \\
\hline & & & & & & & & \\
\hline \multirow[t]{2}{*}{ State Income Tax Revenue Elasticity 1980-1989 } & & & & & & & & $0.334^{* *}$ \\
\hline & & & & & & & & $(0.162)$ \\
\hline \multirow[t]{2}{*}{ Constant } & $2.365 * * *$ & $1.157^{* *}$ & $1.082^{* *}$ & $1.046 * *$ & $1.454 * * *$ & $1.295 * * *$ & $1.376 * * *$ & $0.749 * * *$ \\
\hline & $(0.244)$ & $(0.437)$ & $(0.458)$ & $(0.451)$ & $(0.414)$ & $(0.446)$ & $(0.428)$ & $(0.224)$ \\
\hline Adjusted R-squared & 0.0201 & 0.211 & 0.197 & 0.210 & 0.167 & 0.166 & 0.159 & 0.0786 \\
\hline Observations & 40 & 40 & 40 & 40 & 40 & 40 & 40 & 39 \\
\hline \multicolumn{9}{|c|}{$\begin{array}{l}\text { Source: Author's calculations. State tax revenue data from the Census Bureau, AGI data from the Internal Revenue Service, Statistics of Income Division, and personal income data from BEA/Haver } \\
\text { Analytics. } \\
\text { Note: Standard errors are in parentheses. Regressions exclude New Mexico due to the state's gradual reduction in capital gains taxation over the decade. The 1990-1999 regression also excludes } \\
\text { Connecticut. Stars denote significant difference from zero. }{ }^{*} p<0.1^{* *} p<0.05^{* * *} p<0.01 .\end{array}$} \\
\hline
\end{tabular}


Figure 1: The Composition of State Tax Revenues

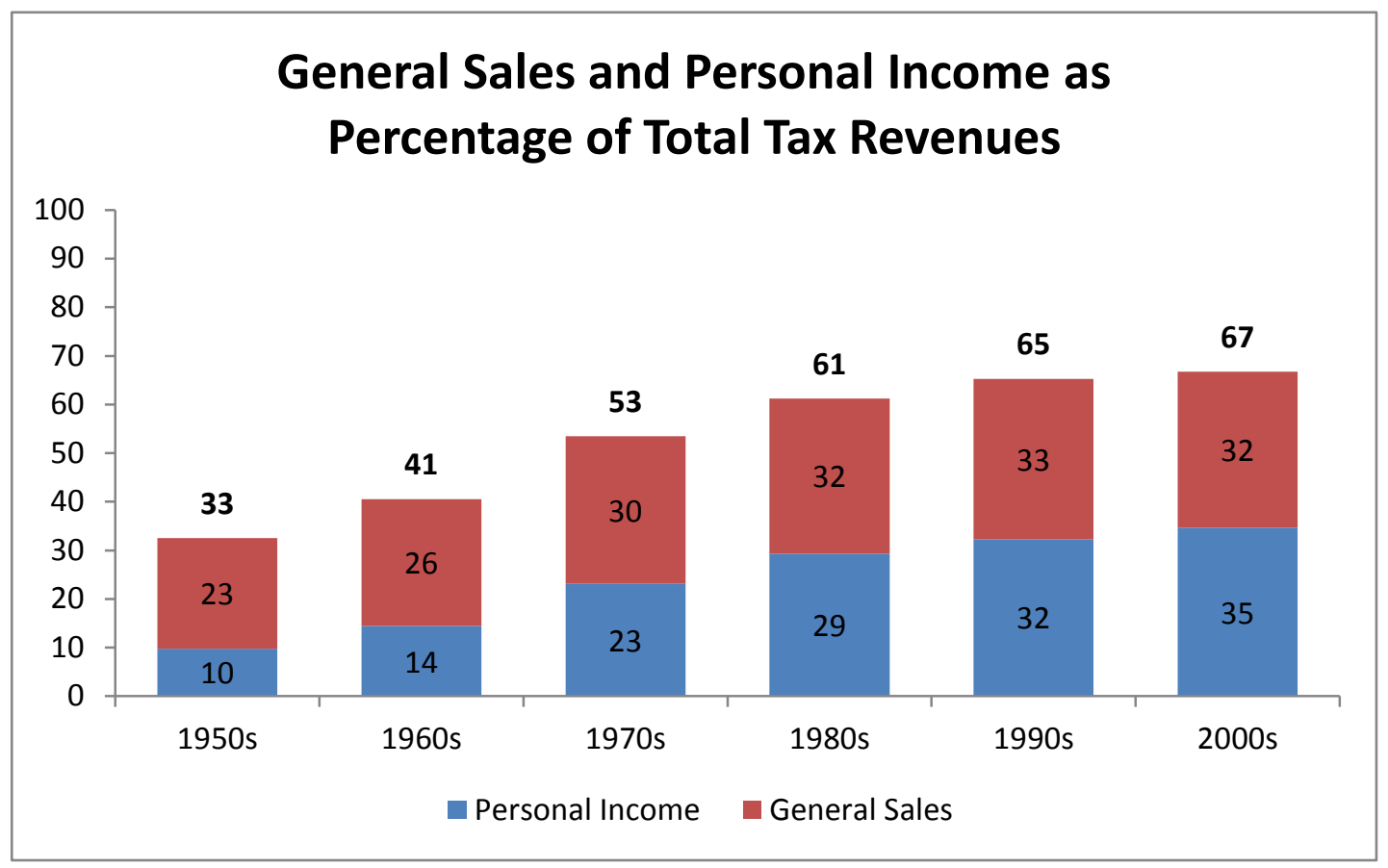

Source: Author's calculations based on data from the Census Bureau/Haver Analytics. 

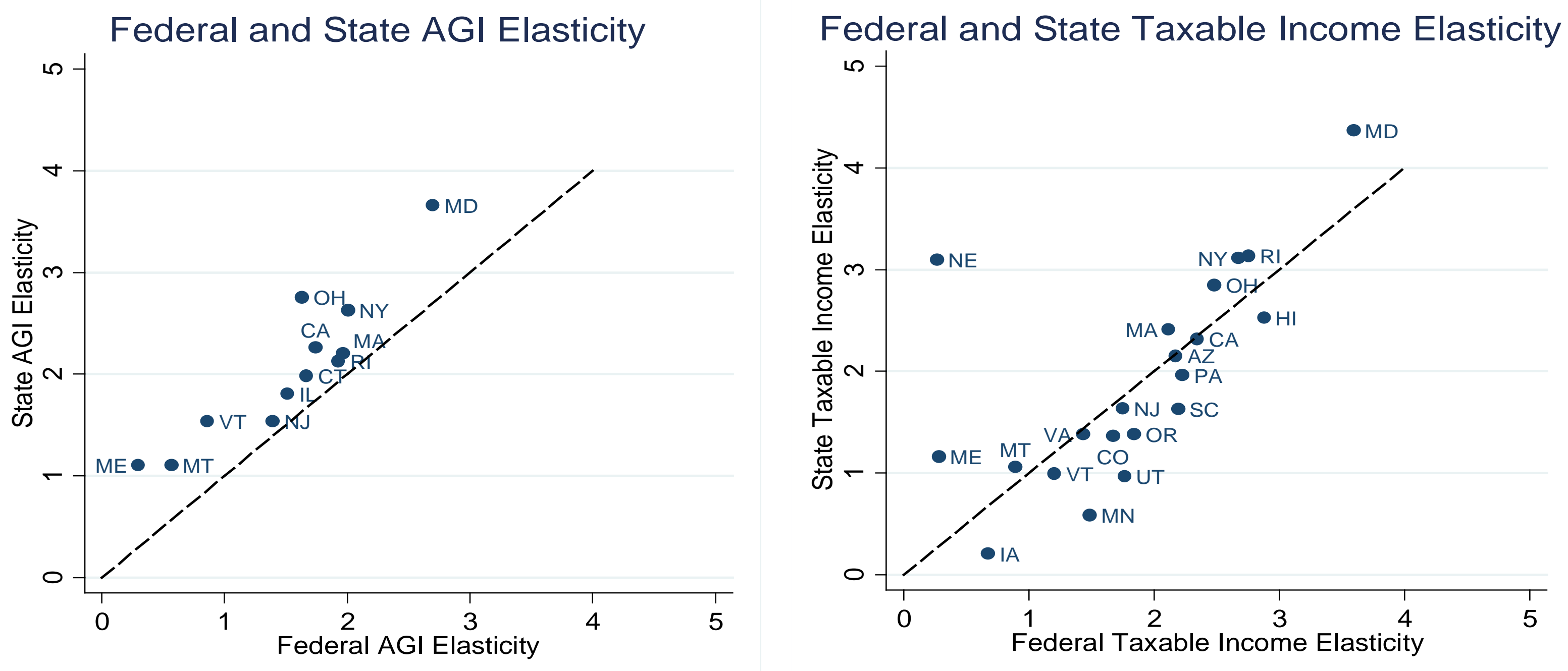

----- 45-Degree Line

Source: Author's calculations based on federal AGI data from the Internal Revenue Service, Statistics of Income Division, personal income data from BEA/Haver Analytics, tax revenue data from the Census Bureau, and state AGI, taxable income, and tax before credits data from state revenue/finance departments.

Note : Analysis restricted to the twenty-three states for which data was available for six or more years in the 2000's. See Appendix Table 4 for exact dates used in each state and federal AGI, taxable income, and tax liability elasticity calculations. 


\begin{tabular}{|c|c|c|c|}
\hline \multicolumn{4}{|c|}{ Appendix Table 1: State Total Tax Revenue Elasticities, 1980-2012 } \\
\hline \multicolumn{4}{|c|}{ Total Tax Revenue Elasticity Relative to Personal Income } \\
\hline & & & \\
\hline & 1980-1999 & 2000-2012 & $\begin{array}{c}2000-2012 \text { versus } \\
1980-1999 \\
\end{array}$ \\
\hline 50-State Average & $0.829 * * *$ & $1.763 * * *$ & $0.934 * * *$ \\
\hline Standard Deviation & $(0.130)$ & $(0.089)$ & $(0.156)$ \\
\hline $\begin{array}{l}\text { 40-State Average (Excluding Mining- } \\
\text { Intensive States) }\end{array}$ & $0.845 * * *$ & $1.533 * * *$ & $0.688 * * *$ \\
\hline Standard Deviation & $(0.128)$ & $(0.121)$ & $(0.174)$ \\
\hline Mining-Intensive State Average & $0.771 * * *$ & $2.158^{* * *}$ & $1.387^{* * *}$ \\
\hline Standard Deviation & $(0.195)$ & $(0.138)$ & $(0.237)$ \\
\hline Alaska $^{+}$ & 1.266 & 4.317 & 3.051 \\
\hline Alabama & $1.754^{* *}$ & 2.026 & 0.271 \\
\hline Arkansas & 0.986 & $0.891 * * *$ & $-0.094^{* * *}$ \\
\hline Arizona & 1.045 & 1.736 & 0.692 \\
\hline California & $1.569^{* *}$ & 2.256 & 0.686 \\
\hline Colorado & 0.899 & 1.909 & 1.010 \\
\hline Connecticut & 0.672 & 1.452 & 0.780 \\
\hline Delaware & 0.968 & 0.992 & 0.024 \\
\hline Florida & $1.593^{* * *}$ & $1.483^{*}$ & $-0.110^{* * *}$ \\
\hline Georgia & $1.386^{* *}$ & 2.388 & 1.002 \\
\hline Hawaii & 0.695 & 1.290 & 0.595 \\
\hline lowa & $-0.529 * * *$ & $1.051^{* * *}$ & 1.580 \\
\hline Idaho & 0.887 & 2.056 & 1.170 \\
\hline Illinois & 0.988 & 1.775 & 0.787 \\
\hline Indiana & 1.569 & 0.911 & $-0.658^{* *}$ \\
\hline Kansas & $-0.437^{* *}$ & 1.091 & 1.528 \\
\hline Kentucky $^{+}$ & 0.635 & 1.793 & 1.158 \\
\hline Louisiana $^{+}$ & $1.737^{* *}$ & $2.265^{* * *}$ & 0.528 \\
\hline Massachusetts & 0.820 & 1.909 & 1.088 \\
\hline Maryland & 1.383 & 2.172 & 0.789 \\
\hline Maine & $1.544^{* * *}$ & $0.588^{* * *}$ & $-0.956 * * *$ \\
\hline Michigan & $1.502^{* *}$ & 2.207 & 0.705 \\
\hline Minnesota & 0.674 & 1.579 & 0.905 \\
\hline Missouri & 1.385 & 1.340 & -0.045 \\
\hline Mississippi & 1.628 & 1.818 & 0.190 \\
\hline Montana $^{+}$ & 0.312 & $3.369 * * *$ & $3.057^{* * *}$ \\
\hline North Carolina & $1.581^{* * *}$ & 1.595 & 0.014 \\
\hline North Dakota $^{+}$ & $0.289^{* * *}$ & 1.992 & $1.703^{* *}$ \\
\hline Nebraska & $-0.318^{* * *}$ & 1.532 & $1.850^{* * *}$ \\
\hline New Hampshire & 0.807 & $0.718^{* * *}$ & $-0.089 *$ \\
\hline New Jersey & 0.163 & 1.542 & 1.379 \\
\hline New Mexico $^{+}$ & $-0.362 * *$ & 2.033 & 2.395 \\
\hline Nevada & $-0.374 * * *$ & 1.568 & 1.941 \\
\hline New York & 0.565 & $2.205^{* * *}$ & $1.640^{*}$ \\
\hline Ohio & $0.500^{*}$ & 2.732 & $2.232^{* *}$ \\
\hline Oklahoma $^{+}$ & $1.966^{* *}$ & $1.986^{* *}$ & $0.020^{* *}$ \\
\hline Oregon & 1.093 & $3.414^{* * *}$ & $2.321^{* * *}$ \\
\hline Pennsylvania & 0.866 & 1.555 & 0.690 \\
\hline Rhode Island & $-0.029 * * *$ & $1.358^{*}$ & $1.387^{*}$ \\
\hline South Carolina & 1.443 & 2.126 & 0.683 \\
\hline South Dakota & 0.550 & $0.563 * * *$ & $0.014^{* * *}$ \\
\hline Tennessee & $2.370^{* * *}$ & 1.915 & $-0.455^{* * *}$ \\
\hline Texas $^{+}$ & $1.649^{*}$ & $1.509^{*}$ & $-0.141^{* *}$ \\
\hline Utah & 2.273 & 1.745 & -0.528 \\
\hline Virginia & $1.666^{*}$ & $2.448^{* *}$ & 0.782 \\
\hline Vermont & 0.754 & $1.123^{*}$ & 0.369 \\
\hline Washington & $0.227^{* *}$ & $0.771^{* *}$ & 0.543 \\
\hline Wisconsin & $1.723^{* *}$ & $1.036^{* *}$ & $-0.687 * * *$ \\
\hline West Virginia $^{+}$ & 1.199 & $0.943^{* * *}$ & $-0.257^{* * *}$ \\
\hline Wyoming $^{+}$ & 1.177 & 2.195 & 1.018 \\
\hline $\begin{array}{l}\text { Source: Author's calculations based on data } \\
\text { Note: For national regressions, stars denot } \\
\text { difference from the national average. Stand } \\
\text { states" identified in the main text. }{ }^{*} p<0.1\end{array}$ & $\begin{array}{l}\text { Lreau and } B E A / \\
\text { ce from zero. } F \\
\text { ered regionally } \\
1 .\end{array}$ & $\begin{array}{l}\text { tate regres } \\
{ }^{+} \text {is used } t\end{array}$ & $\begin{array}{l}\text { denote significant } \\
\text { he ten "mining- }\end{array}$ \\
\hline
\end{tabular}




\begin{tabular}{|c|c|c|c|}
\hline \multicolumn{4}{|c|}{ Appendix Table 2: State Personal Income Tax Revenue Elasticities, 1980-2012 } \\
\hline \multicolumn{4}{|c|}{ Personal Income Tax Revenue Elasticity Relative to Personal Income } \\
\hline & 1980-1999 & 2000-2012 & $\begin{array}{c}2000-2012 \text { versus } \\
1980-1999\end{array}$ \\
\hline 50-State Average & $0.500 *$ & $2.231 * * *$ & $1.732 * * *$ \\
\hline Standard Deviation & $(0.276)$ & $(0.247)$ & $(0.368)$ \\
\hline $\begin{array}{l}\text { 40-State Average (Excluding Mining- } \\
\text { Intensive States) }\end{array}$ & $0.840 * * *$ & $2.636 * * *$ & $1.797 * * *$ \\
\hline Standard Deviation & $(0.155)$ & $(0.198)$ & $(0.249)$ \\
\hline Mining-Intensive State Average & -0.054 & $1.330 * * *$ & $1.385 * *$ \\
\hline Standard Deviation & $(0.427)$ & $(0.400)$ & $(0.577)$ \\
\hline Alaska $^{+}$ & $\mathrm{n} / \mathrm{a}$ & $\mathrm{n} / \mathrm{a}$ & $\mathrm{n} / \mathrm{a}$ \\
\hline Alabama & 1.25 & $3.279 * * *$ & 2.029 \\
\hline Arkansas & $-0.358^{* *}$ & 2.226 & $2.584^{*}$ \\
\hline Arizona & $-0.912 * * *$ & $3.366 * * *$ & $4.278 * * *$ \\
\hline California & $2.450 * * *$ & $4.081 * * *$ & 1.631 \\
\hline Colorado & 0.028 & 2.375 & 2.347 \\
\hline Connecticut & 1.176 & $3.024^{*}$ & 1.848 \\
\hline Delaware & 0.374 & 1.253 & 0.879 \\
\hline Florida & $\mathrm{n} / \mathrm{a}$ & $\mathrm{n} / \mathrm{a}$ & $\mathrm{n} / \mathrm{a}$ \\
\hline Georgia & 1.138 & $3.107 * *$ & 1.968 \\
\hline Hawaii & $1.131^{*}$ & 0.408 & -0.723 \\
\hline lowa & 0.612 & $1.405^{* *}$ & 0.792 \\
\hline Idaho & 0.948 & 2.318 & 1.370 \\
\hline Illinois & 0.647 & 2.672 & 2.025 \\
\hline Indiana & $2.009 *$ & 1.664 & $-0.345^{*}$ \\
\hline Kansas & -1.395 & 1.372 & 2.767 \\
\hline Kentucky $^{+}$ & 0.395 & 1.376 & 0.982 \\
\hline Louisiana $^{+}$ & 0.823 & 2.285 & 1.463 \\
\hline Massachusetts & 0.443 & $3.056^{*}$ & 2.613 \\
\hline Maryland & 0.756 & 3.402 & 2.646 \\
\hline Maine & $1.841^{*}$ & $1.240 * *$ & $-0.601 * * *$ \\
\hline Michigan & $1.463^{* *}$ & $5.260 * * *$ & $3.797^{*}$ \\
\hline Minnesota & 0.343 & 2.509 & 2.165 \\
\hline Missouri & 0.759 & 2.200 & 1.441 \\
\hline Mississippi & $2.153^{*}$ & 2.010 & $-0.142 * *$ \\
\hline Montana $^{+}$ & 1.168 & 2.523 & 1.355 \\
\hline North Carolina & 1.112 & 2.847 & 1.735 \\
\hline North Dakota $^{+}$ & $-0.762 * * *$ & $-0.143 * * *$ & $0.620 * *$ \\
\hline Nebraska & $-0.816^{* * *}$ & $1.226^{*}$ & 2.043 \\
\hline New Hampshire & $\mathrm{n} / \mathrm{a}$ & $\mathrm{n} / \mathrm{a}$ & $\mathrm{n} / \mathrm{a}$ \\
\hline New Jersey & 0.104 & 2.719 & 2.616 \\
\hline New Mexico $^{+}$ & 0.956 & 3.301 & 2.345 \\
\hline Nevada & $\mathrm{n} / \mathrm{a}$ & $\mathrm{n} / \mathrm{a}$ & $\mathrm{n} / \mathrm{a}$ \\
\hline New York & 1.023 & $2.986 * *$ & 1.963 \\
\hline Ohio & 0.158 & $5.043^{*}$ & $4.885^{* *}$ \\
\hline Oklahoma $^{+}$ & $1.850 * *$ & $1.762^{*}$ & $-0.088 * * *$ \\
\hline Oregon & 1.114 & $3.985 * * *$ & $2.871^{*}$ \\
\hline Pennsylvania & 0.310 & 2.599 & 2.289 \\
\hline Rhode Island & 0.082 & 2.689 & 2.607 \\
\hline South Carolina & 1.372 & $5.735^{* * *}$ & $4.363^{* * *}$ \\
\hline South Dakota & $\mathrm{n} / \mathrm{a}$ & $\mathrm{n} / \mathrm{a}$ & $\mathrm{n} / \mathrm{a}$ \\
\hline Tennessee & $\mathrm{n} / \mathrm{a}$ & $\mathrm{n} / \mathrm{a}$ & $\mathrm{n} / \mathrm{a}$ \\
\hline Texas $^{+}$ & $\mathrm{n} / \mathrm{a}$ & $\mathrm{n} / \mathrm{a}$ & $\mathrm{n} / \mathrm{a}$ \\
\hline Utah & $2.375^{* *}$ & 1.923 & $-0.452 * * *$ \\
\hline Virginia & 1.502 & $3.535^{* * *}$ & 2.033 \\
\hline Vermont & $1.532 *$ & $3.162 * * *$ & 1.630 \\
\hline Washington & $\mathrm{n} / \mathrm{a}$ & $\mathrm{n} / \mathrm{a}$ & $\mathrm{n} / \mathrm{a}$ \\
\hline Wisconsin & $3.287 * * *$ & 2.975 & $-0.312^{*}$ \\
\hline West Virginia $^{+}$ & 1.216 & $1.286^{*}$ & $0.071 * *$ \\
\hline Wyoming $^{+}$ & $\mathrm{n} / \mathrm{a}$ & $\mathrm{n} / \mathrm{a}$ & $\mathrm{n} / \mathrm{a}$ \\
\hline $\begin{array}{l}\text { Source: Author's calculations based on data frc } \\
\text { Note: For national regressions, stars denote si } \\
\text { significant difference from the national averag } \\
\text { ten "mining-states" identified in the main text. }\end{array}$ & $\begin{array}{l}\text { ensus Bureau ar } \\
\text { difference from } \\
\text { ard errors are clc } \\
{ }_{* *} \mathrm{p}<0.05^{* * *}\end{array}$ & $\begin{array}{l}\text { er Analytics. } \\
\text { ndividual state } \\
\text { egion by half } \mathrm{d}\end{array}$ & $\begin{array}{l}\text { ions, stars denote } \\
+{ }^{+} \text {is used to denote the }\end{array}$ \\
\hline
\end{tabular}




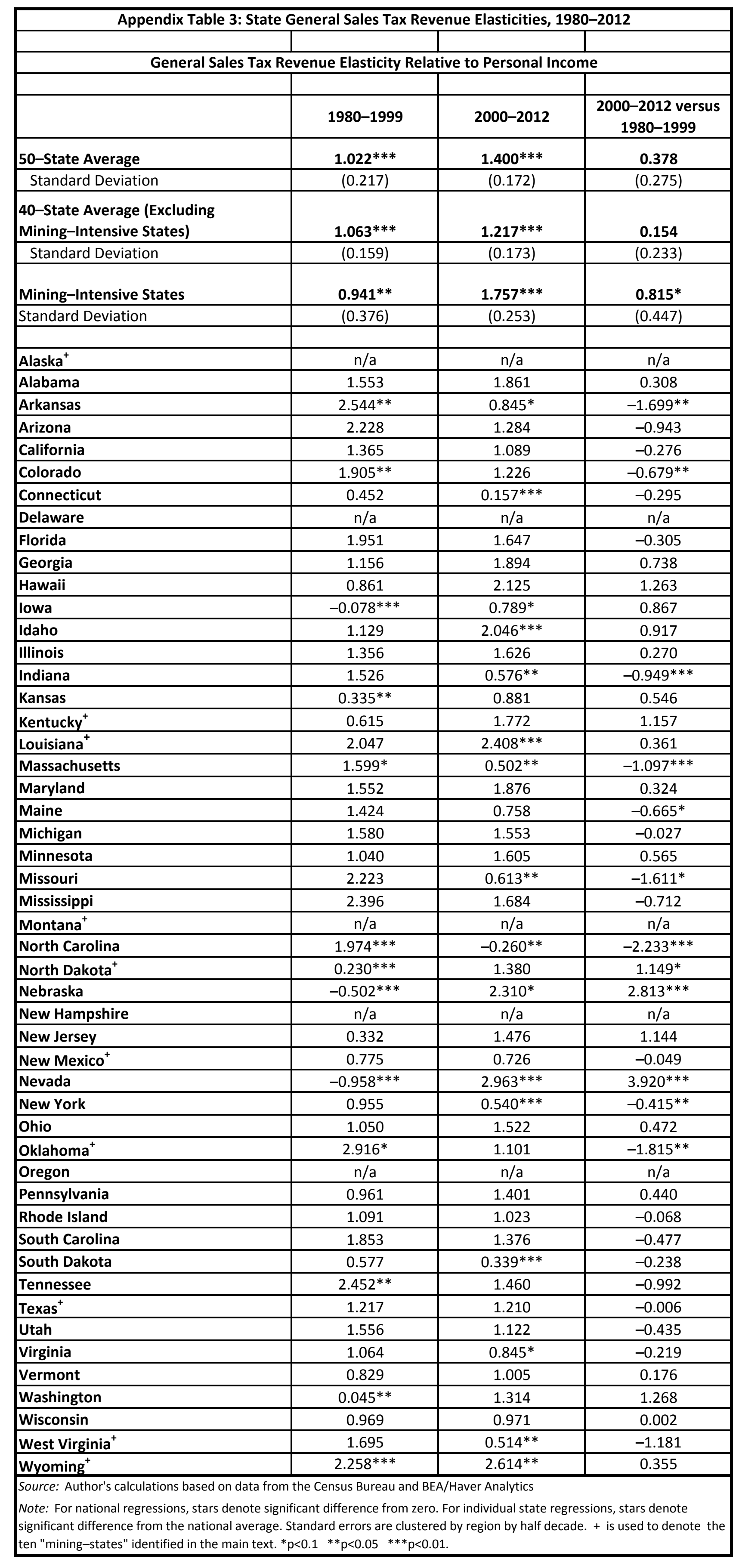




\begin{tabular}{|c|c|c|c|c|c|c|}
\hline \multicolumn{7}{|c|}{ Appendix Table 4: Cyclicality of Selected Income Tax Items Relative to Personal Income, 2000-2012 } \\
\hline & \multicolumn{3}{|c|}{ AGI } & \multicolumn{3}{|c|}{ Taxable Income } \\
\hline & Federal & State & Years Available & Federal & State & Years Available \\
\hline Arizona & $\mathrm{n} / \mathrm{a}$ & $\mathrm{n} / \mathrm{a}$ & $\mathrm{n} / \mathrm{a}$ & 2.175 & $2.151^{* * *}$ & $2000-2009$ \\
\hline California & 1.740 & $2.259^{*}$ & $2000-2010$ & 2.347 & 2.32 & $2000-2010$ \\
\hline Colorado & $\mathrm{n} / \mathrm{a}$ & $\mathrm{n} / \mathrm{a}$ & $\mathrm{n} / \mathrm{a}$ & 1.674 & $1.366^{* * *}$ & 2000-2009 \\
\hline Connecticut & 1.667 & $1.985^{*}$ & $2000-2011$ & $\mathrm{n} / \mathrm{a}$ & $\mathrm{n} / \mathrm{a}$ & $\mathrm{n} / \mathrm{a}$ \\
\hline Hawaii & $\mathrm{n} / \mathrm{a}$ & $\mathrm{n} / \mathrm{a}$ & $\mathrm{n} / \mathrm{a}$ & 2.880 & $2.526^{* * *}$ & 2000-2005 \\
\hline Illinois & 1.514 & 1.804 & $2000-2011$ & $\mathrm{n} / \mathrm{a}$ & $\mathrm{n} / \mathrm{a}$ & $\mathrm{n} / \mathrm{a}$ \\
\hline lowa & $\mathrm{n} / \mathrm{a}$ & $\mathrm{n} / \mathrm{a}$ & $\mathrm{n} / \mathrm{a}$ & 0.675 & $0.206^{* * *}$ & $2000-2011$ \\
\hline Maine & 0.298 & 1.107 & $2000-2011$ & 0.282 & 1.162 & $2000-2011$ \\
\hline Maryland & 2.700 & $3.66 * * *$ & $2001-2008$ & 3.595 & 4.369 & $2001-2008$ \\
\hline Massachusetts & 1.967 & 2.203 & $2000-2011$ & 2.118 & $2.412^{* *}$ & 2004-2011 \\
\hline Minnesota & $\mathrm{n} / \mathrm{a}$ & $\mathrm{n} / \mathrm{a}$ & $\mathrm{n} / \mathrm{a}$ & 1.486 & $0.584 * * *$ & $2005-2010$ \\
\hline Montana & 0.566 & 1.103 & $2000-2011$ & 0.893 & 1.058 & $2000-2011$ \\
\hline Nebraska & $n / a$ & $\mathrm{n} / \mathrm{a}$ & $\mathrm{n} / \mathrm{a}$ & 0.264 & 2.924 & 2003-2011 \\
\hline New Jersey & 1.393 & $1.536^{*}$ & $2000-2010$ & 1.749 & $1.632 * * *$ & $2000-2010$ \\
\hline New York & 2.006 & $2.627^{* * *}$ & 2000-2009 & 2.675 & $3.114^{*}$ & 2000-2009 \\
\hline Ohio & 1.632 & $2.753^{* * *}$ & $2000-2010$ & 2.481 & $2.847^{* * *}$ & $2000-2010$ \\
\hline Oregon & $\mathrm{n} / \mathrm{a}$ & $\mathrm{n} / \mathrm{a}$ & $\mathrm{n} / \mathrm{a}$ & 1.842 & 1.908 & 2001-2011 \\
\hline Pennsylvania & $n / a$ & $\mathrm{n} / \mathrm{a}$ & $\mathrm{n} / \mathrm{a}$ & 2.226 & 1.962 & $2000-2011$ \\
\hline Rhode Island & 1.930 & 2.13 & $2006-2011$ & 2.755 & $3.134 * *$ & $2006-2011$ \\
\hline South Carolina & $n / a$ & $\mathrm{n} / \mathrm{a}$ & $\mathrm{n} / \mathrm{a}$ & 2.192 & $1.626^{* * *}$ & $2002-2011$ \\
\hline Utah & $\mathrm{n} / \mathrm{a}$ & $\mathrm{n} / \mathrm{a}$ & $\mathrm{n} / \mathrm{a}$ & 1.765 & 0.969 & 2000-2007 \\
\hline Vermont & 0.862 & $1.534^{* * *}$ & 2004-2011 & 1.207 & $0.994^{* *}$ & 2004-2011 \\
\hline Virginia & $\mathrm{n} / \mathrm{a}$ & $\mathrm{n} / \mathrm{a}$ & $\mathrm{n} / \mathrm{a}$ & 1.436 & 1.381 & $2000-2010$ \\
\hline \multicolumn{7}{|c|}{$\begin{array}{l}\text { Source: Author's calculations based on federal AGI data from the Internal Revenue Service, Statistics of Income Division, personal income data from BEA/Haver Analytics, tax } \\
\text { revenue data from the Census Bureau, and state AGI and taxable income data from state revenue/finance departments. }\end{array}$} \\
\hline \multicolumn{7}{|c|}{$\begin{array}{l}\text { Note: Standard errors are clustered regionally by half decade. Arizona, Colorado, Hawaii, lowa, Minnesota, Nebraska, Oregon, Pennsylvania, South Carolina, Utah, and Virginia } \\
\text { do not collect or do not report state AGI data. State data for Arizona, California, Connecticut, Hawaii, lowa, Maryland, Minnesota, Montana, New Jersey, New York Oregon, } \\
\text { Rhode Island, Utah, and Vermont reflect only full-year resident returns. Data for other states reflect all returns. All calculations based on yearly log-differences. Stars denote } \\
\text { significant state difference from national AGl or taxable income elasticity. }{ }^{*} p<0.1^{* *} p<0.05 \quad{ }^{* * *} p<0.01 .\end{array}$} \\
\hline
\end{tabular}

